Illinois State University

ISU ReD: Research and eData

Theses and Dissertations

$3-28-2020$

\title{
The Role Of Floating Gardens To Alter The Water Quality Of The Chicago River: Chicago, II
}

Emmett Andrew Spooner

Illinois State University, emmettspooner@yahoo.com

Follow this and additional works at: https://ir.library.illinoisstate.edu/etd

Part of the Geology Commons, and the Hydrology Commons

\section{Recommended Citation}

Spooner, Emmett Andrew, "The Role Of Floating Gardens To Alter The Water Quality Of The Chicago River: Chicago, II" (2020). Theses and Dissertations. 1311.

https://ir.library.illinoisstate.edu/etd/1311

This Thesis is brought to you for free and open access by ISU ReD: Research and eData. It has been accepted for inclusion in Theses and Dissertations by an authorized administrator of ISU ReD: Research and eData. For more information, please contact ISUReD@ilstu.edu. 


\section{THE ROLE OF FLOATING GARDENS TO ALTER THE WATER QUALITY OF THE CHICAGO RIVER: CHICAGO, IL}

\section{EMMETT ANDREW SPOONER}

\section{Pages}

The pollution of heavy metals within surface water is a rising global concern. As heavy metals are transported through rivers, they can bioaccumulate through the food web, leading to harmful concentrations within waterways. In urban areas such as the city of Chicago, Illinois, the use of road salts is a concern as elevated concentrations of chloride $\left(\mathrm{Cl}^{-}\right)$can reduce surface water quality. Since surface waters can carry heavy metals and $\mathrm{Cl}^{-}$salts over a large distance, methods of in-situ phytoremediation are of growing importance. Through a pilot project, a floating garden system has been installed along a portion of the Chicago River. This work aims to answer the following question: Do floating gardens alter the heavy metal concentrations of surface water? To address this question, two hypotheses were proposed: 1) Heavy metal (Al, As, $\mathrm{Be}, \mathrm{Cd}, \mathrm{Cu}, \mathrm{Cr}, \mathrm{Mn}, \mathrm{Zn}$ ) concentrations of surface waters upstream from the floating gardens will be higher than the concentrations downstream. 2) The floating gardens will alter metal concentrations more during the growing season (summer) than the dormant season (winter). To test these hypotheses, surface water samples were collected and analyzed for heavy metals and Cl- upstream and downstream of the floating gardens during both the growing and dormant seasons. The results of this study show a lack of heavy metal presence in the waters. Due to this, the effectiveness of the floating gardens in removing heavy metal concentrations was unable to be determined. This study is useful in understanding heavy metal concentrations in the Chicago River and can serve to support studies on changing concentrations in the river. 
KEYWORDS: floating garden, heavy metals, surface water, urban, wetland 


\title{
THE ROLE OF FLOATING GARDENS TO ALTER THE WATER QUALITY OF THE CHICAGO RIVER: CHICAGO, IL
}

\author{
EMMETT ANDREW SPOONER
}

\author{
A Thesis Submitted in Partial \\ Fulfillment of the Requirements \\ for the Degree of \\ MASTER OF SCIENCE \\ Department of Geography, Geology, and the Environment \\ ILLINOIS STATE UNIVERSITY
}

2020 
(C) 2020 Emmett Andrew Spooner 


\title{
THE ROLE OF FLOATING GARDENS TO ALTER THE WATER QUALITY OF THE CHICAGO RIVER: CHICAGO, IL
}

\author{
EMMETT ANDREW SPOONER
}

COMMITTEE MEMBERS:

Eric Peterson, Chair

Christopher Hamaker

Bill Perry

Catherine O’Reilly 


\section{ACKNOWLEDGMENTS}

Thank you to Dr. Peterson, Dr. Perry, Dr. O’Reilly, Dr. Hamaker, and Dr. Thayn at Illinois State University for their help in the planning and success of this project. Thank you to Jack Wang and Tony Ludwig for assistance in chemical analysis. Thank you to Phil Nicodemus of Urban Rivers for allowing us to access the field site and for providing additional insight into the gardens. Thank you to the Society of Wetland Scientists and the Illinois Lake Management Association for providing funding.

E.A.S. 


\section{CONTENTS}

$\begin{array}{lr} & \text { Page } \\ \text { ACKNOWLEDGMENTS } & \text { i } \\ \text { CONTENTS } & \text { ii } \\ \text { TABLES } & \text { iv } \\ \text { FIGURES } & \text { v }\end{array}$

CHAPTER I: INTRODUCTION AND BACKGROUND 1

Heavy Metal Pollution $\quad 1$

$\begin{array}{ll}\text { Chloride Pollution } & 4\end{array}$

$\begin{array}{ll}\text { Phytoremediation } & 6\end{array}$

Floating Wetlands and Floating Gardens $\quad 8$

$\begin{array}{ll}\text { Objective } & 10\end{array}$

CHAPTER II: METHODOLOGY 11

$\begin{array}{ll}\text { Study Area } & 11\end{array}$

$\begin{array}{ll}\text { Water Sampling } & 17\end{array}$

$\begin{array}{ll}\text { Chemical Analysis } & 18\end{array}$

$\begin{array}{ll}\text { Data Analysis } & 20\end{array}$

$\begin{array}{ll}\text { CHAPTER III: RESULTS } & 21\end{array}$

$\begin{array}{ll}\text { Heavy Metals } & 21\end{array}$

$\begin{array}{ll}\text { Other Parameters } & 24\end{array}$

Dissolved Oxygen $\quad 24$

$\begin{array}{ll}\mathrm{pH} & 25\end{array}$ 
$\begin{array}{lr}\text { Chloride } & 25\end{array}$

$\begin{array}{ll}\text { CHAPTER IV: DISCUSSION } & 27\end{array}$

$\begin{array}{ll}\text { Absence of Metals } & 27\end{array}$

$\begin{array}{ll}\text { Chloride Interaction with Metals } & 31\end{array}$

Role of Gardens $\quad 31$

$\begin{array}{ll}\text { Study Limitations and Future Directions } & 32\end{array}$

$\begin{array}{ll}\text { Potential Error } & 33\end{array}$

$\begin{array}{ll}\text { CHAPTER V: CONCLUSION } & 34\end{array}$

$\begin{array}{ll}\text { REFERERNCES } & 35\end{array}$

APPENDIX A: HEAVY METAL CONCENTRATIONS 43

APPENDIX B: CHLORIDE CONCENTRATIONS 48

APPENDIX C: FIELD PARAMETERS 


\section{TABLES}

Table

Page

1. Plant Species that have Experienced Successful Growth in the Floating Gardens

2. North Branch of Chicago River: Two Miles Upstream of the Floating Gardens; Chicago Water Metropolitan Reclamation District

3. South Branch of Chicago River: Three Miles Downstream of the Floating Gardens; Chicago Water Metropolitan Reclamation District

4. Stock Standard Solutions from Inorganic Ventures

5. Final Standard Concentrations used for Calibration Curves

6. Detection Limits of ICP-AES at Illinois State University, Provided by Tony Ludwig

7. Upstream vs. Downstream Concentrations of DO, $\mathrm{pH}$, and Temperature During the Growing and Dormant Seasons

8. Upstream Growing vs. Upstream Dormant and Downstream Growing vs. Downstream Dormant for DO, $\mathrm{pH}$, and Temperature

9. Upstream vs. Downstream Concentrations of $\mathrm{Cl}^{-}$During the Growing and Dormant Seasons

10. Upstream Growing vs. Upstream Dormant and Downstream Growing vs. Downstream Dormant for $\mathrm{Cl}^{-}$ 


\section{FIGURES}

Figure

Page

1. Goose Island Canal in Relation to Chicago, Illinois 14

2. Study Location on the Eastern Edge of Goose Island Canal 15

3. Floating Substrate Made of Coconut Husk Used for Planting on the Gardens 16

4. View from East to West Showing the Natural Bank on the Opposite Side of the Floating Gardens

5. Upstream and Downstream Sampling Locations

6. Sampling Events During Both the Growing (Top Row) and Dormant (Bottom Row) Seasons

7. Upstream vs. Downstream Values for the Growing and Dormant Seasons

8. Upstream vs. Downstream Chloride Concentrations during Both the Growing and Dormant Seasons 


\section{CHAPTER I: INTRODUCTION AND BACKGROUND}

\section{Heavy Metal Pollution}

The pollution of heavy metals within surface and groundwater is a rising global concern (Vaze and Chiew, 2002; Hnat'uková et al., 2009; Trujillo-González et al., 2016; Chen et al., 2018; Kobielska et al., 2018; Lu et al., 2018). Heavy metals such as aluminum (Al), arsenic (As), cadmium $(\mathrm{Cd})$, chromium $(\mathrm{Cr})$, copper $(\mathrm{Cu})$, lead $(\mathrm{Pb})$, mercury $(\mathrm{Hg})$, nickel $(\mathrm{Ni})$, manganese $(\mathrm{Mn})$, and zinc $(\mathrm{Zn})$ can be detrimental to both the environment and human health (Kobielska et al., 2018). While some heavy metals such as $\mathrm{Cu}, \mathrm{Mn}$, and $\mathrm{Cr}$ are essential for human health, excess amounts can be toxic (Rubio Armendáriz et al., 2015; Saha et al., 2017). Essential heavy metals such as $\mathrm{Cu}, \mathrm{Cr}, \mathrm{Mn}, \mathrm{Se}$, and $\mathrm{Zn}$ influence biochemical and physical functions of plants and animals as they are an important part of enzymes and can influence oxidation-reduction reactions (Marchand et al., 2010).

Heavy metals are considered a priority pollutant of watersheds and can cause adverse effects to the ecosystems they pollute (Saha et al., 2017). Metals such as $\mathrm{Hg}, \mathrm{Cd}$, and $\mathrm{Pb}$ pose a high risk to human health and are highly toxic even at low concentrations (Kavcar et al., 2009; Saha and Zaman, 2013; Saha et al., 2017). Some of the negative effects on human health include hair loss (Cr) (Salem et al., 2000), brain and kidney damage (Cu) (Salem et al., 2000; Wuana and Okieimen, 2011; Ali et al., 2013), cancer of the lungs (Ni) (Salem et al., 2000; Khan et al., 2007; Ali et al., 2013), and impaired development in children (Pb) (Salem et al., 2000; Wuana and Okieimen, 2011; Ali et al., 2013). The formation of free radicals by heavy metals causes oxidative stress, which can attack DNA and lead to cell damage (Ali et al., 2013; Jaishankar et al., 2014). The effect of heavy metals on the blood cells of fish include: a wrinkled cell 
membrane, cell nucleolus damage and shifting, and nucleus destruction which can lead to anemia or death in fish species (Shah, 2017).

While natural sources contribute to heavy metal pollution, the majority of pollution around the study site stems from anthropogenic activities that can be related to production processes and disposal of metal alloys (Bradl, 2005; Wuana and Okieimen, 2011; Kobielska et al., 2018). Within the urbanized Chicago River (IL) watershed, the primary sources of heavy metal pollution are from the drainage of impervious areas, domestic wastewater, and industrial wastewater. The majority of the pollution in urban water sources is related to road input caused by an increase in stormwater runoff (Vaze and Chiew, 2002; Trujillo-González et al., 2016). The accumulation of road dusts within urban areas can deposit inorganic minerals such as $\mathrm{Cu}, \mathrm{Cd}, \mathrm{Cr}$, $\mathrm{Pb}$, and $\mathrm{Zn}$ on the impermeable surfaces of roads and roofs within the city (Trujillo-González et al., 2016). In addition to the accumulation of road dusts, urban streams may receive pollution via discharge from combined sewage overflows (CSOs) (Hnat'uková et al., 2009).

In the portion of the Chicago River located around Goose Island in Chicago, Illinois (Figure 1 and Figure 2), large impermeable areas of urban landscape are drained into the river. Four CSO locations near the north and south ends of the canal discharge directly into the canal during high rainfall events. CSOs are utilized to manage the mixture of urban runoff and municipal wastewater and to transport stormwater and wastewater from homes, businesses, and industries in one single pipe (Hnat'uková, 2011). Due to the limiting capabilities of single pipe transport, high flow events create issues within these combined sewage systems. Periods of continuous rainfall result in an overfilling of these systems. To handle the overfilling, a portion of the flow is discharged directly into streams and rivers through CSO, increasing heavy metal concentrations in water (Komínková et al., 2016). Upstream from the CSO, the concentrations 
for $\mathrm{Cu}, \mathrm{Pb}$, and $\mathrm{Zn}$ were $4.5 \mu \mathrm{g} / \mathrm{L}, 1.8 \mu \mathrm{g} / \mathrm{L}$, and $7 \mu \mathrm{g} / \mathrm{L}$ to $22 \mu \mathrm{g} / \mathrm{L}$, respectively. While downstream the concentrations for $\mathrm{Cu}, \mathrm{Pb}$, and $\mathrm{Zn}$ increased to $9.6 \mu \mathrm{g} / \mathrm{L}, 4.8 \mu / \mathrm{L}$, and $27 \mu \mathrm{g} / \mathrm{L}$. Upon discharging to aquatic ecosystems, the metals are divided between solid and liquid phases that affect stream water and stream sediment (Komínková et al., 2016). In the aquatic phase, heavy metals can undergo precipitation and co-precipitation, which can create insoluble compounds. Iron oxides can co-precipitate copper, nickel, zinc, and manganese while manganese oxides can co-precipitate nickel and zinc (Sheoran and Sheoran, 2006). The surfaces for coprecipitation are highly dependent upon $\mathrm{pH}$. Under acidic conditions, iron oxides are positively charged and can co-precipitate oxyanions of selenium such as selenite while under alkaline conditions, the surfaces are negatively charged and can co-precipitate cationic copper, zinc, nickel, and cadmium (Sheoran and Sheoran, 2006).

Although the metals in stream sediments are generally immobile, variations in $\mathrm{pH}$, salinity, and redox potential cause the release of metals back into the aqueous phase (Hnat'uková et al., 2009), leading to the remobilization and increased bioavailability of heavy metals (Hnatuková, 2011). At contaminated sites the most abundant heavy metals are $\mathrm{Pb}, \mathrm{Cr}, \mathrm{As}, \mathrm{Zn}$, Cd, and Hg (Wuana and Okieimen, 2011). As heavy metals are transported through rivers, they can be absorbed by algae and bioaccumulate through the food web, leading to harmful concentrations within the soils and waterways. Bioaccumulation can occur by either direct toxicity to plants and wildlife or from secondary toxicity to animals feeding on contaminated organisms. (Beringer et al., 2007). The metal concentrations in biota are dependent upon development stage, behavior, sex, and history of exposure in an organism (Komínková et al., 2016). 


\section{Chloride Pollution}

Beginning in the 1940s, sodium chloride $(\mathrm{NaCl})$ was used as a deicing agent for roadways. The application of road salts has increased since then to account for increasing urbanization (Jackson and Jobbagy, 2005; Kelly et al., 2008). The continual use of road salts is a concern as elevated concentrations of chloride $\left(\mathrm{Cl}^{-}\right)$can run off of the impervious surfaces in cities (Kelly et al., 2008; Ludwikowski and Peterson, 2018) and reduce the quality of surface water (Ludwikowski and Peterson, 2018; Willmert et al., 2018). Annually, 270,000 tons of road salts are applied to the roads in the Chicago, Illinois region (Kelly et al., 2008; Friederici, 2004). Wastewater treatment plants are another main source of chloride pollution and add an estimated 175,000 metric tons of salt per year to the Chicago region (Kelly et al., 2012). The combined sewage systems in the city of Chicago deliver the road salt runoff and discharge from wastewater treatment plants directly into surface streams and rivers (Kelly et al., 2012). Since $\mathrm{Cl}^{-}$is highly soluble in water, the majority of $\mathrm{Cl}^{-}$is transported via urban runoff into water bodies and can affect the biota within an ecosystem (Kelly et al., 2009).

In urban areas, the concentrations of $\mathrm{Cl}^{-}$can exceed the levels for freshwater life to survive. In addition, ecosystem functions can be altered at lower than lethal levels (Kelly et al., 2008). While there are no studies on the effects of chloride on aquatic life in the Chicago area, a study by Corsi et al. (2010) in Milwaukee, WI indicated high concentrations of chloride in urban streams had negative affects to several aquatic species. The chloride concentrations ranged from $1000 \mathrm{mg} / \mathrm{L}$ up to $7,730 \mathrm{mg} / \mathrm{L}$ in 8 of the 14 streams studied, elevated above the $860 \mathrm{mg} / \mathrm{L} \mathrm{EPA}$ acute water quality criteria (Corsi et al., 2010). In all 14 of the study locations, the chloride concentrations exceeded the EPA chronic water quality criteria of $230 \mathrm{mg} / \mathrm{L}$. At concentrations above $1770 \mathrm{mg} / \mathrm{L}$ the water flea, $C$. dubia, was unable to reproduce and at concentrations above 
$2420 \mathrm{mg} / \mathrm{L}$ mortality occurred. For the freshwater minnow, P. promelas, reduced weight and survival occurred when concentrations reached $2920 \mathrm{mg} / \mathrm{L}$.

The elevated salt concentration coupled with elevated heavy metal concentrations and temperature changes can further inhibit ecosystem functions (Kelly et al., 2008). Chloride altered soil can mobilize heavy metals by inducing ion exchange, lowering the $\mathrm{pH}$ of the soil, and causing colloid dispersion (Bäckström et al., 2004). The two main processes controlling the increase in heavy metal mobility due to salinity are: 1) the chemical bonding of salt anions with heavy metals, and 2) the exchange of salt cations with positively charged heavy metals (Paalman et al., 1994; Norrström, 2005; Acosta et al., 2011). Concentrations of Cd, $\mathrm{Cu}, \mathrm{Ni}$, and $\mathrm{Zn}$ detected in wetland effluent shows a dramatic increase during periods of deicing, (Bäckström et al., 2004; Huber et al., 2016) and during the winter season the surface runoff system becomes a source of contamination. Thus, the interaction between metals and salt necessitates the analysis of $\mathrm{Cl}^{-}$as it is important to consider heavy metal release in areas prone to traffic area runoff (Huber et al., 2016). Norrstrom (2005) applied $3.55 \mathrm{~g} / \mathrm{L}(0.1 M)$ of $\mathrm{NaCl}$ into two soil columns and found that $37 \%$ and $45 \%$ of $\mathrm{Cd}$ was released from each column respectively. Road salt as $\mathrm{NaCl}$ results in a large remobilization of $\mathrm{Cd}, \mathrm{Cu}$, and $\mathrm{Pb}$, while road salt as $\mathrm{MgCl}_{2}$ releases higher levels of Cd (Nelson et al., 2009; Huber et al., 2016). The mobilization of Pb can be increased by de-icing salts as it is driven by negatively charged particle transport (Norrström, 2005). However, the overall extent of mobilization depends upon the type and amount of heavy metals present, the type of salt influencing salinization, the soil properties, and the hydrogeology (Norrström, 2005; Acosta et al., 2011). 


\section{Phytoremediation}

With the increasing concentrations of heavy metals in the environment, methods for remediation are of great importance. Remediation can be accomplished by physical, chemical, or biological means. Current methods of remediation include isolation, immobilization, physical separation, and extraction (Wuana and Okieimen, 2011; Ali et al., 2013). The practice of these methods is determined by the cost, effectiveness, availability, general acceptance, toxicity reduction, and the ability to be used with mixed wastes (Wuana and Okieimen, 2011). In general, the physical and chemical methods are more expensive and require intense labor. In addition, physical and chemical methods can cause harmful changes in soil properties and can create secondary pollution problems (Ali et al., 2013). An environmentally friendly and cost-effective solution to this problem is phytoremediation.

Phytoremediation refers to the use of plants and their associated microorganisms to degrade, remove, or detoxify hydrocarbons, chlorinated solvents, pesticides, and heavy metals from soil and groundwater (Susarla et al., 2002; Wuana and Okieimen, 2011; Ali et al., 2013). Plants promote the removal of these contaminants by altering the chemical composition of soils, increasing organic carbon, improving oxygen flow into the root zone, intercepting chemical movement, and affecting the microbial and plant enzyme transformations of chemicals (Paterson et al., 1990; Shimp et al., 1993; Simonich and Hites, 1995; Wuana and Okieimen, 2011). While phytoremediation is not the best method for removing high levels of contamination, it is an economical and effective method for removing low levels of pollution (Wuana and Okieimen, 2011).

There are many advantages of phytoremediation when compared to other remediation methods. Phytoremediation (a) is economically practical, (b) does not disrupt the environment, 
(c) is aesthetically pleasing, and (d) can provide resources and habitats for organisms. Some disadvantages include phytoremediation (a) is dependent upon the growth of the plant, (b) is difficult to implement in the large scale, (c) requires the plants to be tolerant to the pollutant, (d) can release contaminated plants back into the environment, and (e) it requires plant disposal sites (Wuana and Okieimen, 2011). Phytoremediation involves two mechanisms, phytoextraction and phytofiltration (Wuana and Okieimen, 2011; Ali et al., 2013).

Phytoextraction refers to the uptake of contaminants in soils by plant roots and the subsequent movement of the contaminants into the plant tissues (Wuana and Okieimen, 2011; Singh and Kumar, 2017). After the metals are absorbed at the root surface the metal moves from the cell membrane into the root's cells. Upon reaching the cells, a small portion of the metal is immobilized in the vacuole while the rest crosses the cellular membranes and into the root vascular tissue where it transitions into the stems and leaves, which can be harvested and composted (Wuana and Okieimen, 2011). The high concentrations of metals in the composted plants can be diluted to safe levels by combining contaminated biomass with non-contaminated biomass (Wuana and Okieimen, 2011).

Phytofiltration differs slightly from phytoextraction as the metals are accumulated in the roots and do not get transported into the leaves. This method is beneficial for the removal of metals such as $\mathrm{Pb}, \mathrm{Cd}, \mathrm{Cu}, \mathrm{Cr}$, and $\mathrm{Ni}$ that accumulate in the roots of plants. (Galal et al., 2016; Singh and Kumar, 2017). Galal et al. (2016) revealed significant bioaccumulation factors (BF), or capability of a plant to absorb heavy metals from the soil, for milkweed. For every metal tested, milkweed had a BF greater than one which indicates the accumulation of heavy metals: for $\mathrm{Cd}$ the $\mathrm{BF}$ was 130 , for $\mathrm{Fe}$ the $\mathrm{BF}$ was 9 , for $\mathrm{Mn}$ the $\mathrm{BF}$ was 8 , for $\mathrm{Zn}$ and $\mathrm{Cu}$ the $\mathrm{BF}$ was 7 , 
and for $\mathrm{Pb}$ the $\mathrm{BF}$ was 2 (Galal et al., 2016); indicating that milkweed has good phytoremediation potential.

\section{Floating Wetlands and Floating Gardens}

Artificial floating wetlands are systems designed to enhance surface water interactions with plants, microorganisms, and the atmosphere to remove contaminants from polluted waters (Headley and Tanner, 2008). The use of floating wetlands has been identified as a means to capture harmful nutrient loads on rivers (Li et al., 2010; Zhao et al., 2012; McAndrew and Ahn, 2017; Wang et al., 2018) through phytoextraction and phytofiltration. Floating wetlands have been used successfully for the treatment of stormwater (Kerr-Upal et al., 2000; Headley and Tanner, 2008), combined stormwater-sewer overflow (Tao et al., 2014), and water supply reservoirs (Li et al., 2010). They are composed of a buoyant floating substrate from which wetland plant systems grow. Below the substrate, an extensive network of roots and attached biofilms are developed within the water column (Li et al., 2010; Wang and Sample, 2014; McAndrew and Ahn, 2017). These biofilms contribute to nutrient removal by providing for the biochemical transformation of contaminants (Wang and Sample, 2014) and the filtration of particulates (Headley and Tanner, 2012). The hydroponic growth provides the plants with direct access to the nutrients in the water column. Thus, the nutrient uptake is greater for plants on floating wetlands (Li et al., 2010, Headley and Tanner, 2012; McAndrew and Ahn, 2017; Pavlineri et al., 2017). Specifically, heavy metals may be removed by floating gardens via the capture of fine suspended particulates by roots and biofilms and by the deposition of sediments and their eventual immobilization.

Sedimentation is a principle method in removing heavy metals from water in wetlands and while it is not a straightforward physical reaction, various chemical processes are linked to 
the aggregation and eventual settling of metals. The clay sediment in the riverbed of the Chicago River could serve as a site of adsorption for heavy metals. Heavy metals are adsorbed to organic matter and sediment by cation exchange and can be physically attached to clay and organic matter by electrostatic attraction, leading to a reduction of metals in the water column. Once attached, the metals will remain as metal ions. However, the strength of adsorption is dependent upon element type and the competition with other elements and can result in either short or long term retention (Marchand et al., 2010). Sheoran and Sheoran (2006) found the retention of $\mathrm{Pb}$, $\mathrm{Cu}$, and $\mathrm{Cr}$ by adsorption to be greater than $\mathrm{Zn}$ and $\mathrm{Cd}$ and that greater than $50 \%$ of heavy metals are easily adsorbed and removed by sedimentation.

In a wetland, the biomass of macrophytes can influence the sedimentation of suspended solids and limit erosion by slowing flow velocity and increasing the hydraulic pathways through a system (Lee and Scholz, 2007; Marchand et al., 2010). This is an important factor as the dynamic flow conditions of the Chicago River water can be slowed, and metals may be carried from the water to the substrate/biota of the floating gardens. Upon entering this substrate, the roots of floating plants can serve as traps for suspended solids. Sinicrope et al. (1992) found the efficiency of wetland mesocosms for metal removal to be $75-78 \%$ for cadmium, chromium, and zinc, $84 \%$ for lead, and $55 \%$ for nickel. The majority of these metals were retained in the soils and fine roots.

Several studies have proven that floating gardens are effective on stagnant waters in removing nitrogen, phosphorous, and heavy metals from water and that they have the capability to remove contaminants from water bodies (Zhao et al., 2012; Cao and Zhang, 2014; Wang et al., 2018). Zhao et al. (2012) evaluated the efficiency of a floating island in the removal of nutrients and heavy metals. The study indicated that the average removal rates for total nitrogen and total 
phosphorous during the summer season were $36.9 \%$ and $64.5 \%$ respectively. The average removal rates for $\mathrm{Cr}$ was $79.5 \%$, while the removal of $\mathrm{Cu}, \mathrm{As}, \mathrm{Cd}, \mathrm{Hg}$, and $\mathrm{Pb}$ had an average removal of $48 \%$ (Zhao et al., 2012) and the implementation of floating bed can purify landscape water (Wang et al., 2018). The results of the experiments showed that floating beds could successfully bring down contaminant concentrations to a safe level. While each of these studies are conducted in different ecosystems and utilize different plants for phytoremediation, it is significant to note that they all recorded the effects of floating gardens in a controlled system. The present study will provide insight into the benefits of floating gardens on flowing rivers and could suggest the large-scale applicability to this rising method of remediation.

\section{Objective}

Since surface waters can carry heavy metal and chloride ions over a large distance, methods of in-situ phytoremediation are of growing importance. One promising solution to reduce heavy metal concentrations is the use of floating gardens on streams and rivers. However, floating gardens are a relatively new concept and the majority of studies focus on their effectiveness of nitrogen, phosphorus, and chloride reduction (Zhao et al., 2012; Wang et al., 2018) with little to no information available on the effectiveness of heavy metal reduction in dynamic flow systems. This study works to address the following question: 1) Do floating gardens alter the heavy metal concentrations of the river water? To address this question, two hypotheses were tested: 1) Heavy metal concentrations ( $\mathrm{As}, \mathrm{Cd}, \mathrm{Cr}, \mathrm{Cu}, \mathrm{Fe}, \mathrm{Pb}, \mathrm{Mn}, \mathrm{Se}, \mathrm{Zn}$ ) of the waters upstream from the floating gardens will be higher than the concentrations downstream. 2) The floating gardens will alter the metal concentrations more during the growing season than during the dormant season. 


\section{CHAPTER II: METHODOLOGY}

\section{Study Area}

This study centered on a portion of the Chicago River flowing adjacent to Goose Island in Chicago, Illinois (Figure 1). Goose Island canal was constructed in the 1870's and has undergone periods of channelization and dredging. Because commercial boat traffic is no longer permitted, dredging of the canal has stopped and meters of loose sediment have accumulated on top of hard clay. The canal ranges from 1 meter deep at the northern end to 2.5 meters deep at the southern end and is 24-37 meters in width. The site is focused on the eastern edge of the canal (Figure 2) at a set of artificially constructed floating gardens built from interconnected tubes of coconut husk to provide a buoyant substrate (Figure 3) for local plants, such as Marsh-marigold, Rose mallow, and Blue vervain (Table 1). This artificial habitat provides an ecosystem for aquatic life and introduces both allochthonous and autochthonous organic matter to the river. The eastern bank adjacent to the floating gardens is cement and steel lined, while the bank across from the gardens is natural with trees and plants growing along the river (Figure 4).

The flow conditions at the site are from the northeast to the southwest with a mean discharge of $31 \mathrm{ft}^{3} / \mathrm{s}$ based upon the last 67 years of water data collected by the USGS (U.S. Geologic Survey, 2020). With such conditions, trash buildup and accumulation can occur along the northern edge of the gardens. Next to the study site, large impermeable areas of urban landscape are drained into the canal, which may lead to heavy metal and chloride pollution. The Chicago Metropolitan Water Reclamation District (CMWRD) has collected heavy metal and chloride data on a monthly basis at locations two miles upstream on the North Branch of the Chicago River (Table 2) and three miles downstream on the South Branch of the Chicago River (Table 3 ) of the canal. In 2018, monthly heavy metal concentrations for $\mathrm{As}, \mathrm{Cd}, \mathrm{Cr}, \mathrm{Cu}, \mathrm{Pb}, \mathrm{Mn}$, 
Se, and Zn were less than $2 \mu \mathrm{g} / \mathrm{L}$ on both the North and South Branches of the Chicago River.

The $\mathrm{Cl}^{-}$concentrations peaked at $572 \mathrm{mg} / \mathrm{L}$ in February of 2018 on the South Branch of the

Chicago River and $248 \mathrm{mg} / \mathrm{L}$ in March on the North Branch of the Chicago River.

Table 1: Plant Species that have Experienced Successful Growth in the Floating Gardens

\begin{tabular}{|l|l|}
\hline Species Name & Common Name \\
\hline Acorus calamus & Sweet flag \\
\hline Caltha palustris & Marsh-marigold \\
\hline Carex bromoides & Brome sedge \\
\hline Carex comosa & Bristly sedge \\
\hline Carex stricta & Tussock sedge \\
\hline Decodon verticillatus & Waterwillow \\
\hline Filipendula rubra & Queen of the prairie \\
\hline Hibiscus moscheutos & Rose mallow \\
\hline Iris virginica var. shrevei & Southern blue flag \\
\hline Juncus effusus & Common rush \\
\hline Justicia americana & American water-willow \\
\hline Rumex altissimus & Pale dock \\
\hline Saururus cernuus & Lizards tail \\
\hline Scirpus cyperinus & Woolgrass \\
\hline Verbena hastata & Blue vervain \\
\hline Carex comosa & Longhair sedge \\
\hline Rumex altissmus & Pale dock \\
\hline & \\
\hline
\end{tabular}

Table 2: North Branch Chicago River: Two Miles Upstream of the Floating Gardens; Chicago Water Metropolitan Reclamation District

\begin{tabular}{|r|r|r|r|r|r|r|r|r|r|}
\hline \multicolumn{1}{|c|}{ Date } & $\begin{array}{c}\mathbf{C l} \\
(\mathbf{m g} / \mathbf{L})\end{array}$ & $\begin{array}{c}\mathbf{A s} \\
(\mathbf{m g} / \mathbf{L})\end{array}$ & $\begin{array}{c}\mathbf{C d} \\
(\mathbf{m g} / \mathbf{L})\end{array}$ & $\begin{array}{c}\mathbf{C r} \\
(\mathbf{m g} / \mathbf{L})\end{array}$ & $\begin{array}{c}\mathbf{C u} \\
(\mathbf{m g} / \mathbf{L})\end{array}$ & $\begin{array}{c}\mathbf{P b} \mathbf{s o l} \\
(\mathbf{m g} / \mathbf{L})\end{array}$ & $\begin{array}{c}\mathbf{M n} \\
(\mathbf{m g} / \mathbf{L})\end{array}$ & $\begin{array}{c}\mathbf{S e} \\
(\mathbf{m g} / \mathbf{L})\end{array}$ & $\begin{array}{c}\mathbf{Z n} \\
(\mathbf{m g} / \mathbf{L})\end{array}$ \\
\hline 12-Mar-18 & 248 & $<0.02$ & $<0.001$ & $<0.003$ & 0.005 & $<0.01$ & 0.019 & 0.014 & 0.022 \\
\hline 9-Apr-18 & 229 & $<0.050$ & $<0.005$ & $<0.005$ & $<0.025$ & $<0.030$ & 0.017 & $<0.001$ & $<0.100$ \\
\hline 14-May-18 & 165 & $<0.050$ & $<0.005$ & $<0.005$ & $<0.025$ & $<0.03$ & 0.024 & $<0.05$ & $<0.100$ \\
\hline 11-Jun-18 & 110 & $<0.050$ & $<0.005$ & $<0.005$ & $<0.025$ & $<0.030$ & 0.016 & $<0.050$ & $<0.100$ \\
\hline 16-Jul-18 & 111 & 0.001 & $<0.002$ & $<0.004$ & 0.002 & $<0.002$ & 0.013 & $<0.002$ & 0.018 \\
\hline 13-Aug-18 & 91 & 0.001 & $<0.002$ & $<0.004$ & 0.002 & $<0.002$ & 0.014 & 0.001 & 0.016 \\
\hline 10-Sep-18 & 100 & 0.001 & $<0.002$ & $<0.004$ & 0.002 & $<0.002$ & 0.013 & $<0.002$ & 0.011 \\
\hline 8-Oct-18 & 86 & 0.001 & $<0.002$ & $<0.004$ & 0.004 & 0.002 & 0.027 & $<0.002$ & 0.022 \\
\hline 13-Nov-18 & 122 & $<0.002$ & $<0.002$ & $<0.004$ & 0.003 & $<0.002$ & 0.012 & $<0.002$ & 0.024 \\
\hline 10-Dec-18 & 151 & $<0.002$ & $<0.002$ & $<0.004$ & 0.002 & $<0.002$ & 0.013 & 0.002 & 0.021 \\
\hline
\end{tabular}


Table 3: South Branch Chicago River: Three Miles Downstream of the Floating Gardens; Chicago Water Metropolitan Reclamation District

\begin{tabular}{|c|c|c|c|c|c|c|c|c|c|}
\hline Date & $\begin{array}{c}\mathrm{Cl} \\
(\mathrm{mg} / \mathrm{L})\end{array}$ & $\underset{(\mathrm{mg} / \mathrm{L})}{\mathrm{As}}$ & $\underset{(\mathrm{mg} / \mathrm{L})}{\mathrm{Cd}}$ & $\underset{(\mathrm{mg} / \mathrm{L})}{\mathrm{Cr}}$ & $\underset{(\mathrm{mg} / \mathrm{L})}{\mathrm{Cu}}$ & $\begin{array}{c}\mathrm{Pb} \\
(\mathrm{mg} / \mathrm{L})\end{array}$ & $\begin{array}{c}\text { Mn } \\
(\mathrm{mg} / \mathrm{L})\end{array}$ & $\begin{array}{c}\mathrm{Se} \\
(\mathrm{mg} / \mathrm{L})\end{array}$ & $\underset{(\mathrm{mg} / \mathrm{Ln})}{\mathrm{Zn}}$ \\
\hline 22-Jan-18 & 349 & $<0.02$ & $<0.001$ & $<0.003$ & $<0.004$ & $<0.01$ & 0.026 & $<0.005$ & 0.023 \\
\hline $20-$ Feb-18 & 572 & $<0.02$ & $<0.001$ & $<0.003$ & 0.005 & $<0.01$ & 0.035 & 0.013 & 0.027 \\
\hline 19-Mar-18 & 270 & $<0.02$ & $<0.001$ & $<0.003$ & 0.006 & $<0.01$ & 0.027 & 0.006 & 0.022 \\
\hline 16-Apr-18 & 295 & $<0.050$ & $<0.005$ & $<0.005$ & $<0.025$ & $<0.030$ & 0.043 & $<0.050$ & $<0.100$ \\
\hline 21-May-18 & 166 & $<0.050$ & $<0.005$ & $<0.005$ & $<0.025$ & $<0.03$ & 0.027 & $<0.05$ & $<0.100$ \\
\hline 18-Jun-18 & 73 & $<0.050$ & $<0.005$ & $<0.005$ & $<0.025$ & $<0.030$ & 0.009 & $<0.050$ & $<0.100$ \\
\hline 23-Jul-18 & 70 & 0.001 & $<0.002$ & $<0.004$ & 0.003 & $<0.002$ & 0.009 & $<0.002$ & 0.015 \\
\hline 17-Sep-18 & 57 & 0.001 & $<0.002$ & $<0.004$ & 0.002 & $<0.002$ & 0.007 & $<0.002$ & 0.010 \\
\hline 19-Nov-18 & 132 & $<0.002$ & $<0.002$ & $<0.004$ & 0.003 & $<0.002$ & 0.012 & 0.001 & 0.025 \\
\hline 17-Dec-18 & 156 & $<0.002$ & $<0.002$ & $<0.004$ & 0.003 & $<0.002$ & 0.018 & $<0.002$ & 0.022 \\
\hline
\end{tabular}




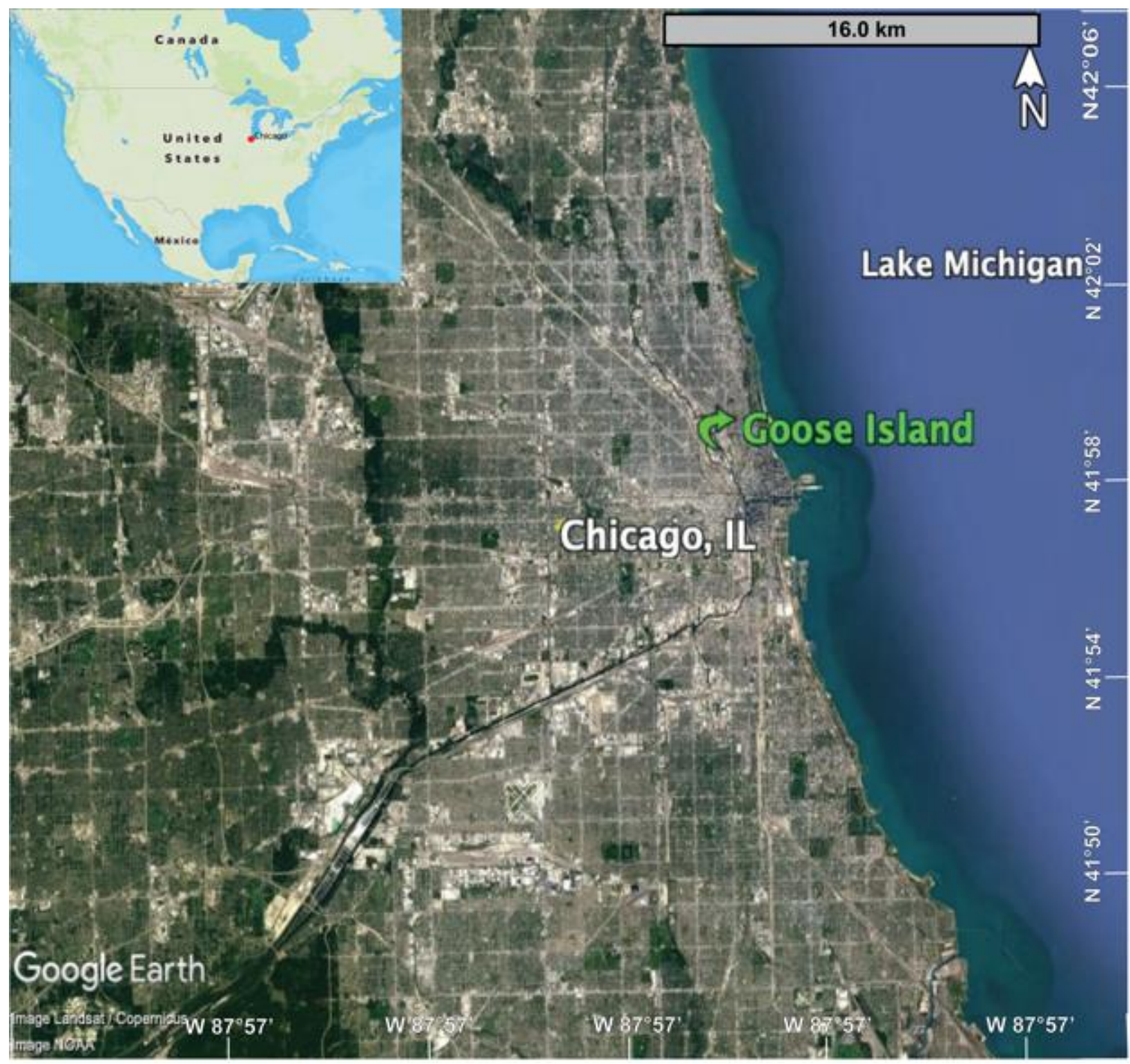

Figure 1: Goose Island Canal in Relation to Chicago, Illinois 


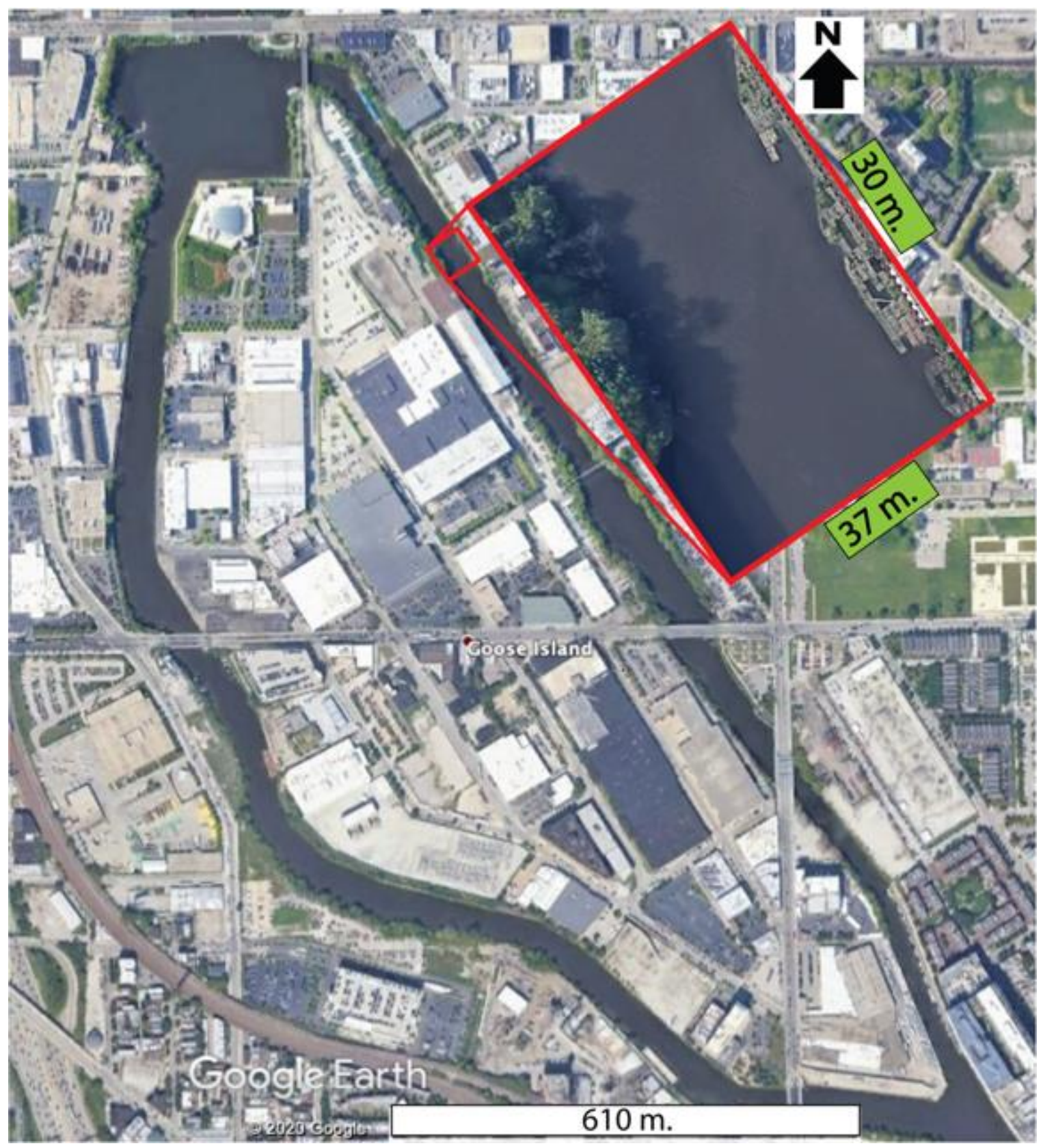

Figure 2: Study Location on the Eastern Edge of Goose Island Canal. It is Important to Make Note of the Garden Size (3 m x $30 \mathrm{~m}$ ) in Relation to the River Size (30 m x $37 \mathrm{~m}$ ). 


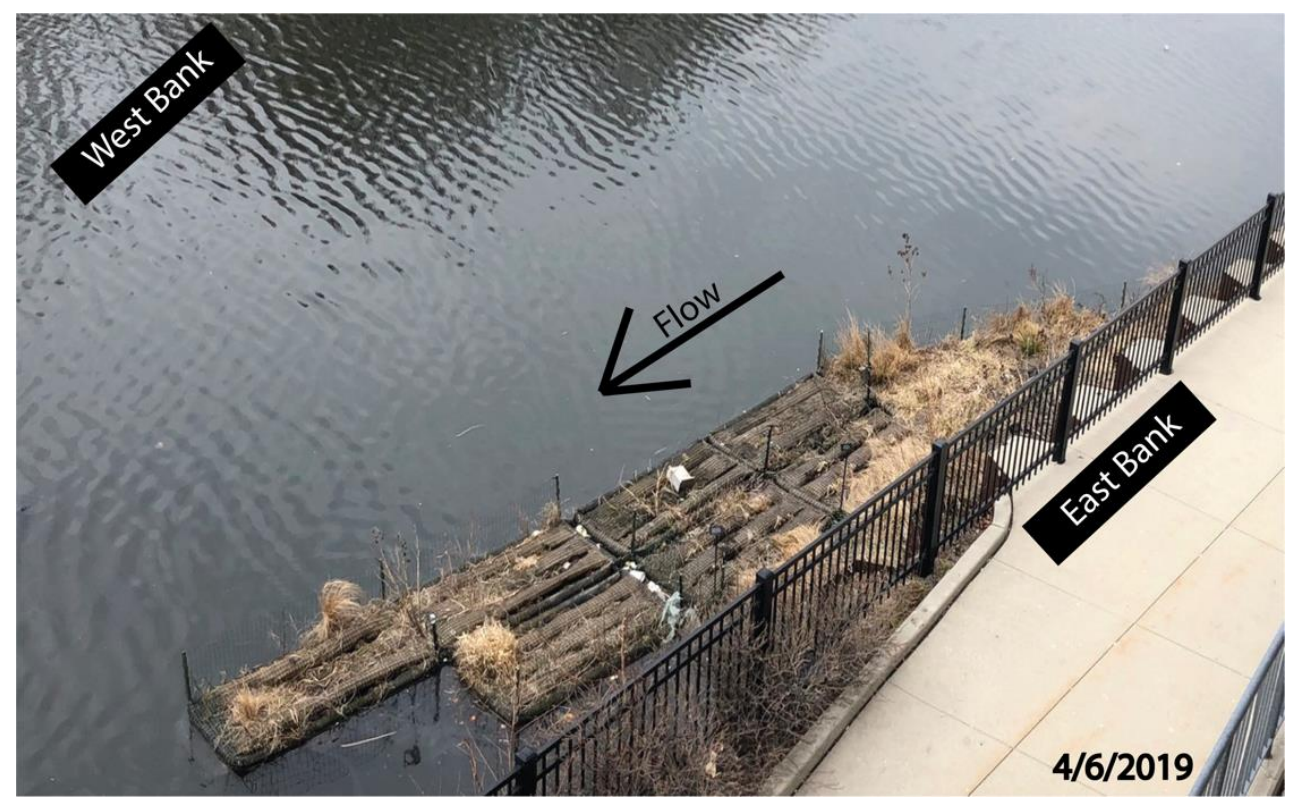

Figure 3: Floating Substrate Made of Coconut Husk Used for Planting on the Gardens.

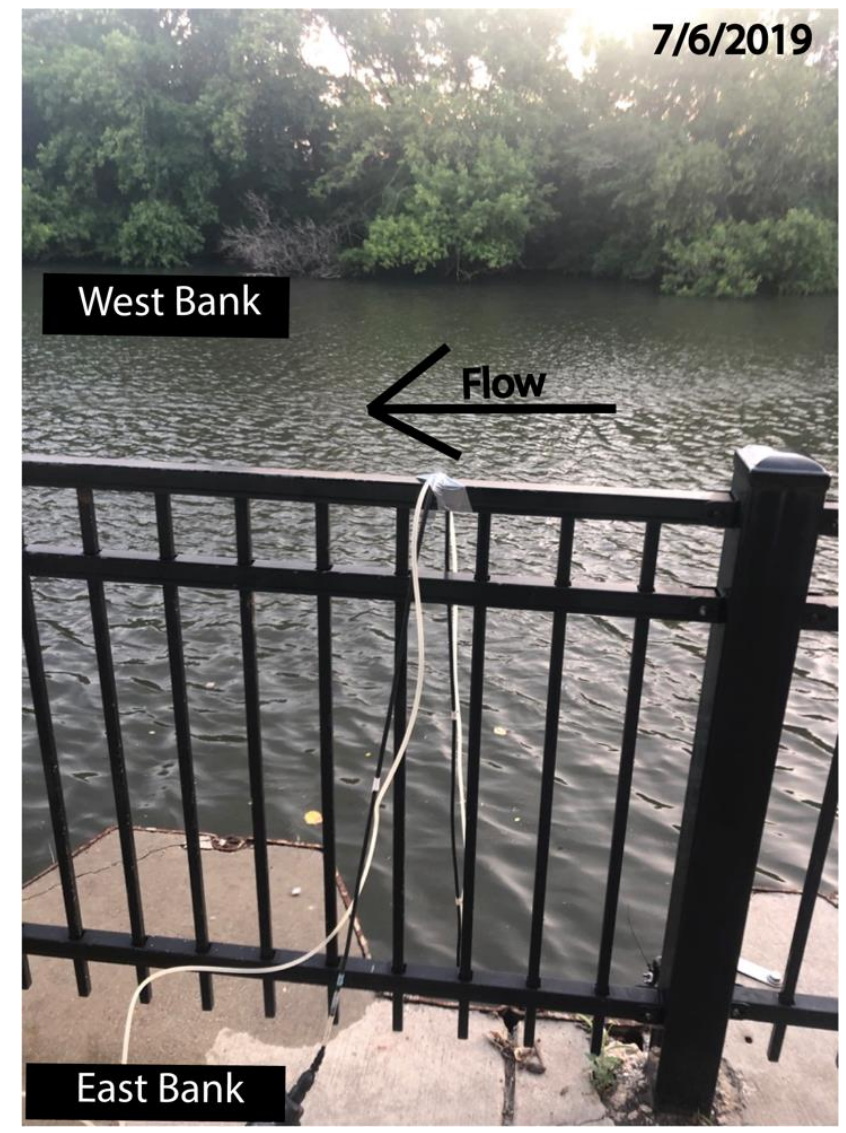

Figure 4: View from East to West Showing the Natural Bank on the Opposite Side of the Floating Gardens. 


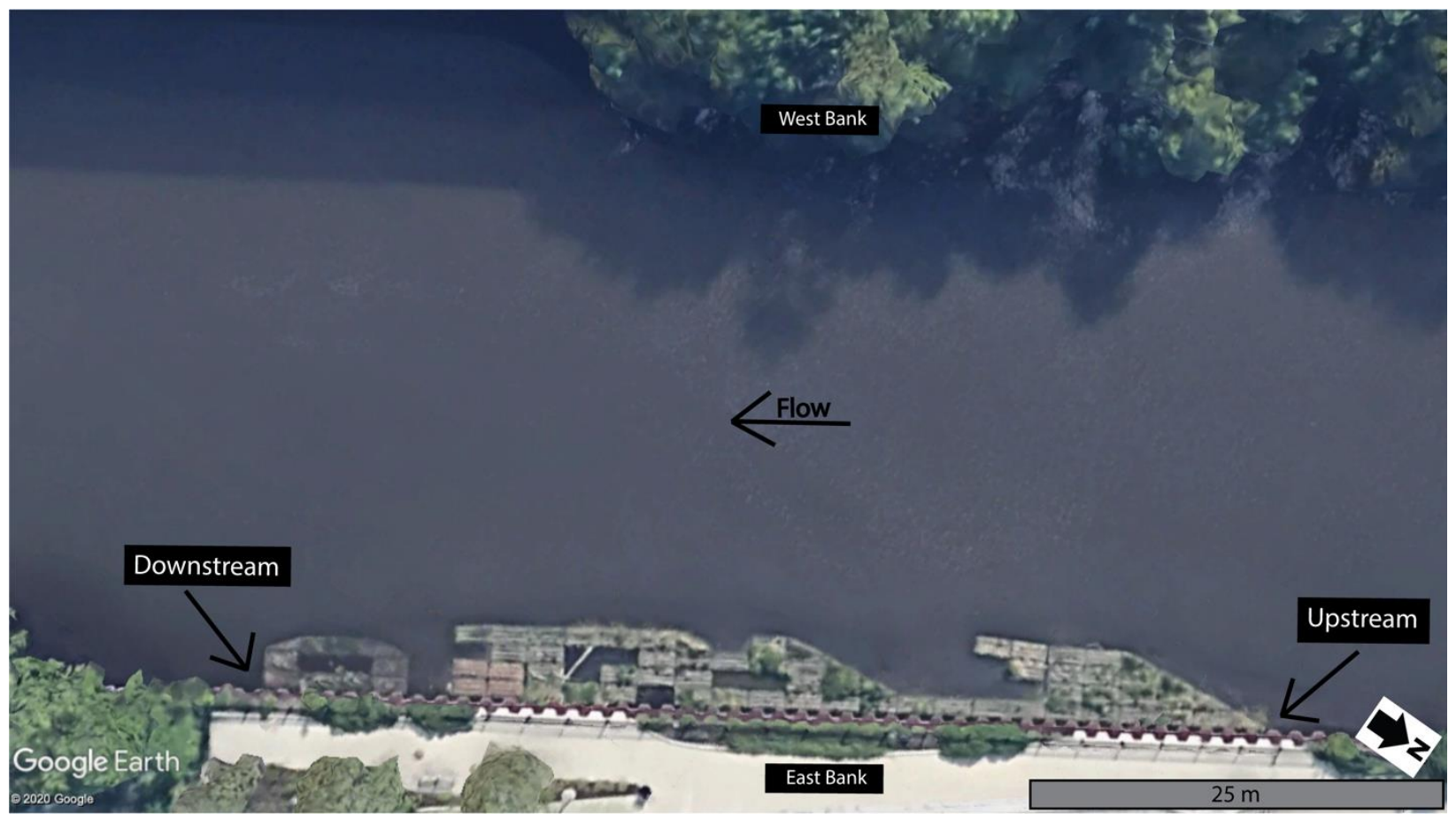

Figure 5: Upstream and Downstream Sampling Locations.

\section{Water Sampling}

Grab samples were drawn $10 \mathrm{~cm}$ below the surface of the river upstream and downstream

(Figure 5) of the floating gardens with a MasterFlex E/S portable sampler during the growing season (July-August) and dormant season (November-December) of the gardens. The dates of sampling for the growing season were: $7 / 6 / 19,7 / 8 / 19,7 / 30 / 19,8 / 5 / 19$, and $8 / 13 / 19$ and the dates for the dormant season were: 10/24/19, 11/5/19, 11/7/19, 11/16/19, and 11/19/19 (Figure 6). During both the growing season and the dormant season, five sampling events took place, each consisting of four sets of 10 water samples. For each upstream and downstream sampling event, 10 grab samples were collected to analyze for heavy metals and 10 grab samples were collected to analyze for anions. Each sample was drawn directly from the upstream or downstream location and placed into an acid washed $30 \mathrm{ml}$ sample bottle. The dissolved heavy metal samples were filtered in the field through a $0.4-\mu \mathrm{m}$ membrane filter and acidified to a $\mathrm{pH}$ of 2 with concentrated sulfuric acid. The anion samples were filtered in the ISU lab with a $0.4-\mu \mathrm{m}$ 
membrane filter prior to analysis. All samples were transported in an ice chest back to ISU where they were then frozen. During each sampling event, a YSI Sonde was used to measure in-situ temperature $\left({ }^{\circ} \mathrm{C}\right)$, dissolved oxygen $(\mathrm{mg} / \mathrm{L})$, and $\mathrm{pH}$.
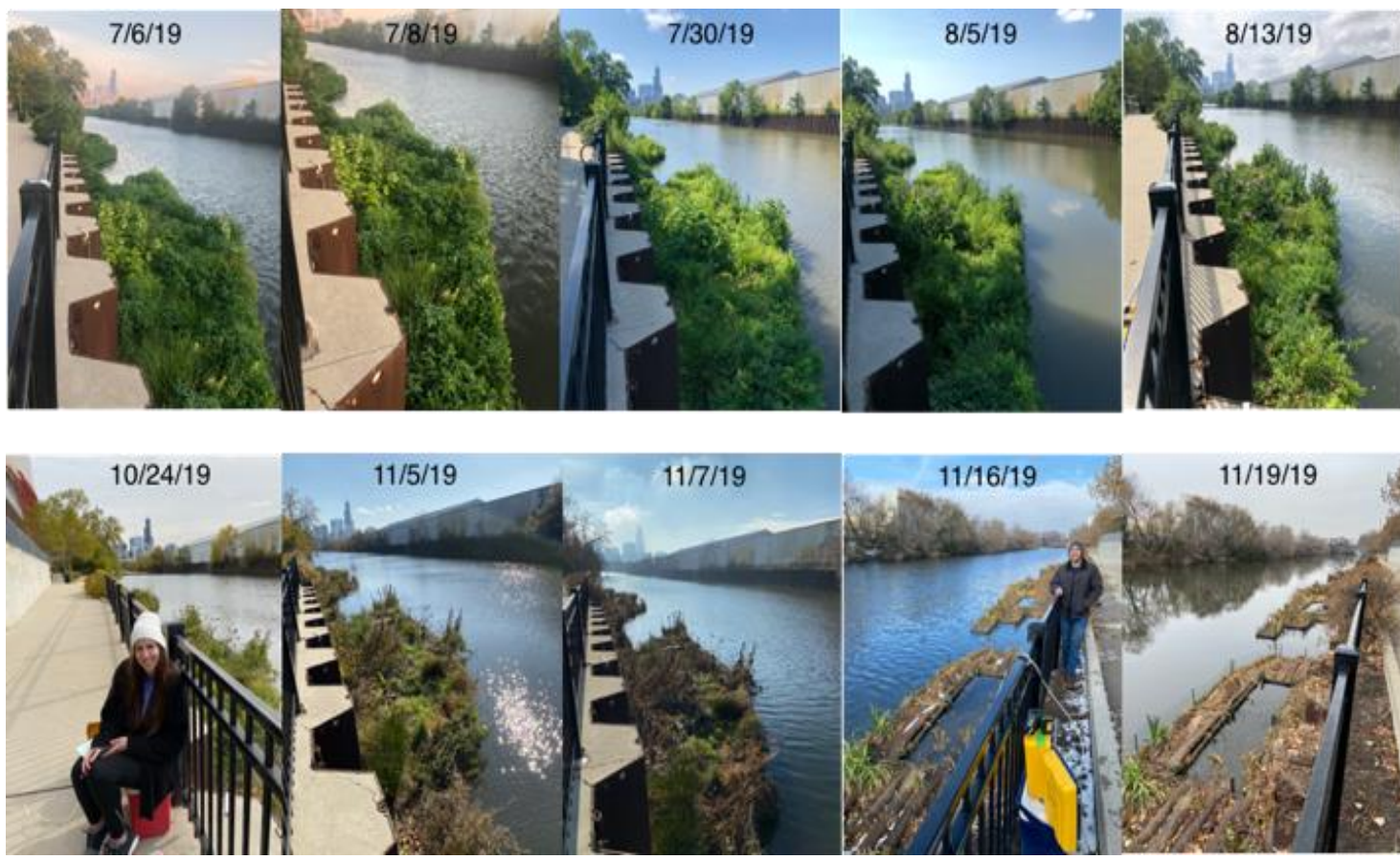

Figure 6: Sampling Events During Both the Growing (Top Row) and Dormant (Bottom Row) Seasons.

\section{Chemical Analysis}

Surface water samples were analyzed for heavy metal concentrations (Al, As, Be, Cd, Cr, $\mathrm{Cu}, \mathrm{Pb}, \mathrm{Mn}, \mathrm{Se}, \mathrm{Zn})$ and anion concentrations $\left(\mathrm{Cl}^{-}\right)$at Illinois State University. Heavy metal concentrations were measured using a PerkinElmer Optima 8300 Inductively Coupled Plasma Atomic Emission Spectrometer (ICP-AES) and anion concentrations were measured on a Dionex ICS-1100 Ion Chromatograph. Metal standards were made by diluting a purchased stock solution from Inorganic Ventures containing all the metals listed in table 4 and the anion $\left(\mathrm{Cl}^{-}\right)$samples were compared to anion standards made in the Illinois State University Laboratory for Environmental Analysis. The detection limits for the ICP-AES (Table 5) were provided by Tony 
Ludwig, the instrument technician for the Illinois State University Chemistry Science Laboratory Building. Sample duplicates, sample blanks, and independent standard calibration were used to maintain quality assurance and quality control.

Table 4: Stock Standard Solutions from Inorganic Ventures

\begin{tabular}{|lr|lr|}
\hline \multicolumn{3}{|c|}{$\begin{array}{c}\text { ICP Calibration Standard- Trace Metals } \\
\text { IV-Stock-13 }\end{array}$} & \multicolumn{2}{c|}{ Matrix: $\mathrm{HNO}_{3}$} \\
\hline Analyte & $\mu \mathrm{g} / \mathrm{mL}$ & Analyte & $\mu \mathrm{g} / \mathrm{mL}$ \\
$\mathrm{Al}$ & 500 & $\mathrm{Cu}$ & 100 \\
$\mathrm{As}$ & 100 & $\mathrm{Mn}$ & 100 \\
$\mathrm{Be}$ & 100 & $\mathrm{~Pb}$ & 100 \\
$\mathrm{Cd}$ & 25 & $\mathrm{Se}$ & 25 \\
$\mathrm{Cr}$ & 100 & $\mathrm{Zn}$ & 100 \\
\hline
\end{tabular}

Table 5: Final Standard Concentrations used for Calibration Curves

\begin{tabular}{|c|c|c|}
\hline \multirow{2}{*}{ Standard } & $\begin{array}{c}\mathbf{A s ,} \mathbf{B e}, \mathbf{C d}, \mathbf{C r}, \mathbf{C u}, \\
\mathbf{M n}, \mathbf{P b}, \mathbf{S e}, \mathbf{Z n}\end{array}$ & Al \\
\cline { 2 - 3 } & $\mu g / L$ & $\mu g / L$ \\
\hline 1 & 0.0001 & 0.001 \\
\hline 2 & 0.001 & 0.005 \\
\hline 3 & 0.01 & 0.05 \\
\hline 4 & 0.1 & 0.5 \\
\hline 5 & 1 & NA \\
\hline
\end{tabular}

Table 6: Detection Limits of ICP-AES at Illinois State University, Provided by Tony Ludwig

\begin{tabular}{|l|r|l|r|}
\hline \multicolumn{4}{|c|}{ Detection Limits-: ICP-AES } \\
\hline Analyte & $\mu \mathrm{g} / \mathrm{L}$ & Analyte & $\mu \mathrm{g} / \mathrm{L}$ \\
\hline $\mathrm{Al}$ & 1 & $\mathrm{Cu}$ & 0.4 \\
\hline $\mathrm{As}$ & 1 & $\mathrm{Mn}$ & 0.1 \\
\hline $\mathrm{Be}$ & 0.09 & $\mathrm{~Pb}$ & 1 \\
\hline $\mathrm{Cd}$ & 0.1 & $\mathrm{Se}$ & 2 \\
\hline $\mathrm{Cr}$ & 0.2 & $\mathrm{Zn}$ & 0.2 \\
\hline
\end{tabular}




\section{Data Analysis}

The data were separated by element (Al, Be, As, Cd, Cl, Cr, Cu, Fe, Pb, Mn, Se, Zn) for the growing season and the dormant season. Due to each of the metals being below the detection limits, no data analysis of the metals occurred. Dissolved oxygen, $\mathrm{pH}$, and temperature values were tested for normality using a Shapiro-Wilks test and found to be normally distributed. Paired t-tests $(\alpha=0.05)$ were used to assess any statistical differences for each pair (upstream vs. downstream). 


\section{CHAPTER III: RESULTS}

\section{Heavy Metals}

To determine the influence of the floating gardens on heavy metal concentrations in the Chicago River, upstream versus downstream data sets from the growing season (July-August) were compared to those of the dormant season (October-November). These sampling events revealed levels below the detection limits (BDL) for each of the tested metals (Al, $\mathrm{As}, \mathrm{Be}, \mathrm{Cd}$, $\mathrm{Cr}, \mathrm{Cu}, \mathrm{Pb}, \mathrm{Mn}, \mathrm{Se}, \mathrm{Zn}$ ) thus data analysis of the heavy metals was unable to occur. However, at concentrations below the detection limit of the ICP-OES, each of the metals were less that the United States Environmental Protection Agency (USEPA) secondary (SMCL) and maximum contaminant levels (MCL) (EPA, 2009; EPA 2020). The USEPA SMCL guideline for Al ranges from $50 \mu \mathrm{g} / \mathrm{L}$ to $200 \mu \mathrm{g} / \mathrm{L}$, the MCL for Be is $4 \mu \mathrm{g} / \mathrm{L}$, for Cd the MCL is $5 \mu \mathrm{g} / \mathrm{L}$, for Cr the MCL is $100 \mu \mathrm{g} / \mathrm{L}$, for Mn the SMCL is $50 \mu \mathrm{g} / \mathrm{L}$ and for $\mathrm{Zn}$ the SMCL is $500 \mu \mathrm{g} / \mathrm{L}$.

Table 7: Upstream vs. Downstream Concentrations of DO, pH, and Temperature During the Growing and Dormant Seasons

\begin{tabular}{|c|c|c|c|c|c|c|c|}
\hline \multirow{2}{*}{ Species } & \multirow{2}{*}{ Location } & \multicolumn{3}{|c|}{ Growing Season } & \multicolumn{3}{|c|}{ Dormant Season } \\
\hline & & $\mathbf{N}$ & Mean & $\mathbf{P}$ & $\mathbf{N}$ & Mean & $\mathbf{P}$ \\
\hline \multirow{2}{*}{ DO (mg./L.) } & Upstream & 5 & 5.28 & \multirow{2}{*}{0.634} & 5 & 6.24 & \multirow{2}{*}{0.381} \\
\hline & Downstream & 5 & 5.17 & & 5 & 6.50 & \\
\hline \multirow{2}{*}{$\mathrm{pH}$} & Upstream & 5 & 7.51 & \multirow{2}{*}{0.215} & 5 & 7.14 & \multirow{2}{*}{0.41} \\
\hline & Downstream & 5 & 7.37 & & 5 & 7.33 & \\
\hline \multirow{2}{*}{ Temp. $\left({ }^{\circ} \mathrm{C}\right)$} & Upstream & 5 & 23.04 & \multirow{2}{*}{0.477} & 5 & 11 & \multirow{2}{*}{0.25} \\
\hline & Downstream & 5 & 23.08 & & 5 & 10.9 & \\
\hline
\end{tabular}


Table 8: Upstream Growing vs. Upstream Dormant and Downstream Growing vs.

Downstream Dormant for DO, $\mathrm{pH}$, and Temperature

\begin{tabular}{|l|r|r|}
\hline \multirow{2}{*}{ Species } & \multicolumn{2}{|c|}{ p-value } \\
\cline { 2 - 3 } & Upstream & Downstream \\
\hline DO (mg./L.) & 0.079 & 0.073 \\
\hline pH & 0.841 & 0.222 \\
\hline Temp. $\left({ }^{\circ} \mathrm{C}\right)$ & $<0.001^{*}$ & $<0.001^{*}$ \\
\hline
\end{tabular}

Table 9: Upstream vs. Downstream Concentrations of $\mathrm{Cl}^{-}$During the Growing and Dormant Seasons

\begin{tabular}{|c|l|r|r|r|r|r|c|}
\hline \multirow{2}{*}{ Species } & \multirow{2}{*}{ Location } & \multicolumn{3}{|c|}{ Growing Season } & \multicolumn{3}{|c|}{ Dormant Season } \\
\cline { 3 - 8 } & & $\mathbf{N}$ & Median (mg/L) & P & N & Median (mg/L) & P \\
\hline \multirow{2}{*}{$\mathrm{Cl}$} & Upstream & 5 & 124.828 & & 5 & 165.839 & \multirow{2}{*}{0.493} \\
\cline { 2 - 7 } & Downstream & 5 & 117.943 & & 5 & 171.227 & \\
\hline
\end{tabular}

Table 10: Upstream Growing vs. Upstream Dormant and Downstream Growing vs. Downstream Dormant for $\mathrm{Cl}^{-}$

\begin{tabular}{|c|l|l|}
\hline \multirow{2}{*}{ Species } & \multicolumn{2}{|c|}{ p-value } \\
\cline { 2 - 3 } & Upstream & Downstream \\
\hline $\mathrm{Cl}(\mathrm{mg} / \mathrm{L})$ & $<0.001$ & $<0.001$ \\
\hline
\end{tabular}



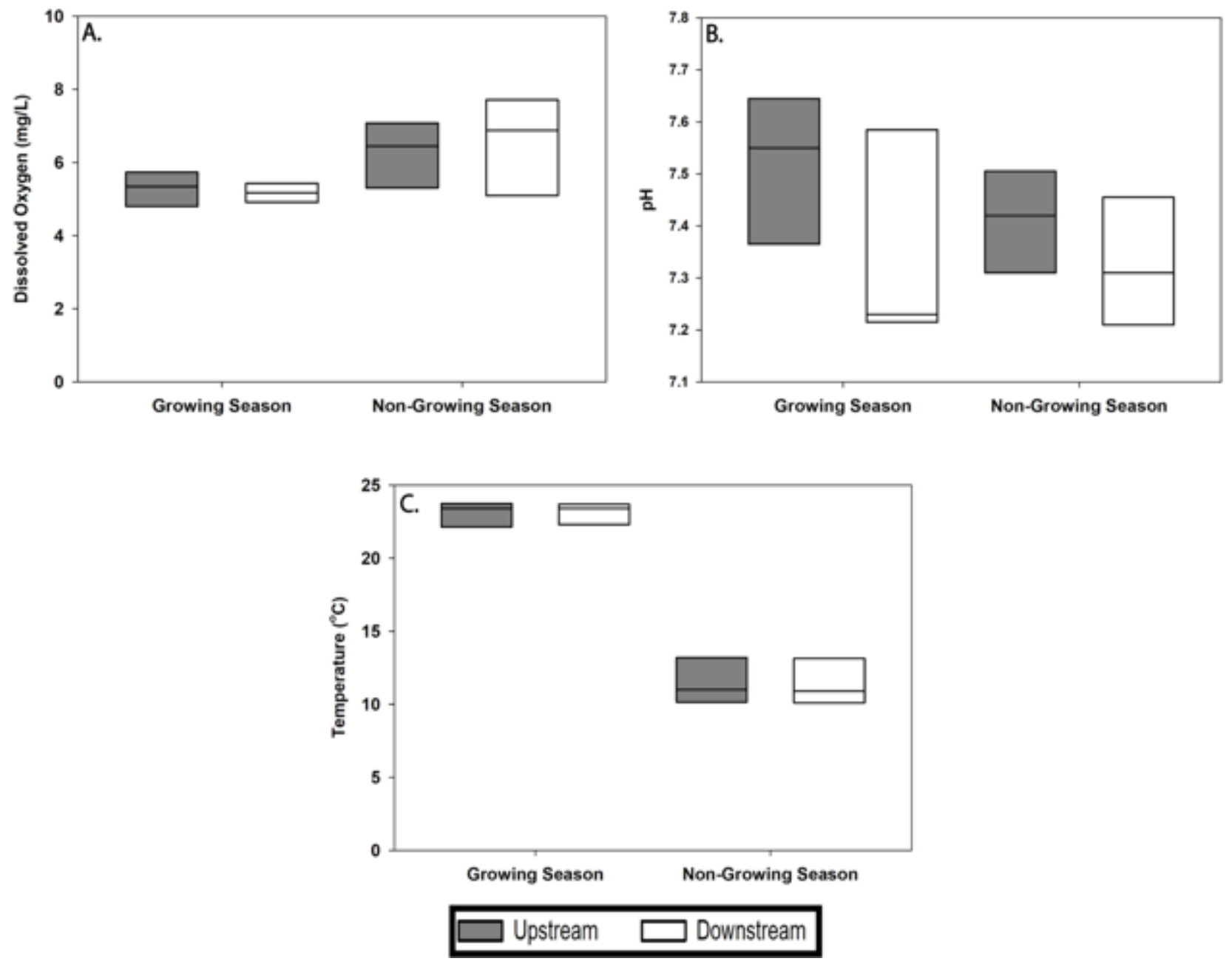

Figure 7: Upstream vs. Downstream Values for the Growing and Dormant Seasons. The Box and Whisker Plots Represent the Range of Concentrations with Outliers Plotted as an Individual Point and the Line Representing the Median Concentrations. A: Dissolved Oxygen, $B: p H, C:$ Temperature 


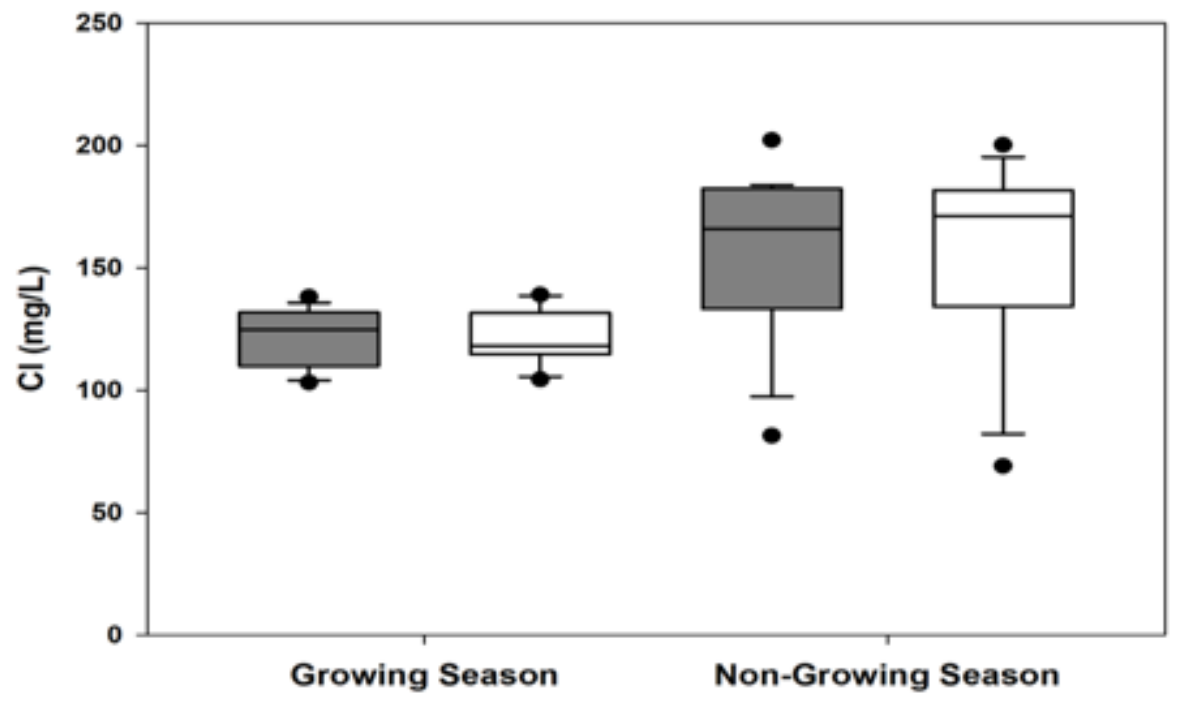

Figure 8: Upstream vs. Downstream Chloride Concentrations During Both the Growing and Dormant Seasons. The Box and Whisker Plots Represent the Range of Concentrations with Outliers Plotted an Individual Point and the Line Representing the Median Concentrations.

\section{Other Parameters}

Dissolved Oxygen

For the growing season, the upstream and downstream mean was $5.28 \mathrm{mg} / \mathrm{L}$ and 5.17 mg./L respectively. For the dormant season, the upstream and downstream mean was $6.24 \mathrm{mg} / \mathrm{L}$ and $6.50 \mathrm{mg} . / \mathrm{L}$ respectively (Figure 7A, Table 7). The results of the paired t-test indicated that there was not a statistically significant difference in upstream vs. downstream concentration during either the growing $(p=0.634)$ or dormant $(p=0.381)$ season. Significant differences were not detected seasonally with $p=0.079$ upstream and $p=0.073$ downstream. The mean up concentration of $5.28 \mathrm{mg} / \mathrm{L}$ in the growing season was not statistically different $(p=0.079)$ from the median value of $6.24 \mathrm{mg} / \mathrm{L}$ measured during the dormant season. The mean downstream concentration in the growing season was not statistically different $(p=0.073)$ from the median value of measured during the dormant season (Table 8). 
$\mathrm{pH}$

For the growing season, the upstream and downstream mean was 7.51 and 7.37 respectively. For the dormant season, the upstream and downstream mean was 7.14 and 7.33 respectively (Figure 7B, Table 7). The results of the paired t-test indicated that there was not a statistically significant difference in upstream vs. downstream $\mathrm{pH}$ during either the growing $(p=$ 0.215 ) or dormant $(p=0.41)$ season. The mean upstream in the growing season was not statistically different $(p=0.81)$ from the mean value measured during the dormant season. The mean downstream $\mathrm{pH}$ in the growing season was statistically different $(p=0.22)$ from the median value measured during the dormant season (Table 8).

\section{Temperature}

For the growing season, the upstream and downstream mean was $23.08{ }^{\circ} \mathrm{C}$ and $23.08{ }^{\circ} \mathrm{C}$, respectively. For the dormant season, the upstream and downstream mean was $11.0^{\circ} \mathrm{C}$ and 10.9 ${ }^{\circ} \mathrm{C}$, respectively (Figure 7C, Table 7). The results of the Paired T-test indicated that there was not a statistically significant difference in upstream vs. downstream concentration during either the growing $(p=0.477)$ or dormant $(p=0.25)$ season. Significant differences were detected seasonally with $\mathrm{P}<0.001$ upstream and downstream. The mean upstream temperature in the growing season was statistically different $(p<0.001)$ from the mean value measured during the dormant season. The mean downstream temperature in the growing season was statistically different $(p<0.001)$ from the mean downstream temperature during the dormant season (Table 8).

\section{Chloride}

Chloride was detected in the water column during both the growing and dormant season with higher concentrations detected during the dormant season (Figure 8, Table 9). For the 
growing season, the upstream and downstream median was $124.8 \mathrm{mg} / \mathrm{L}$ and $117.9 \mathrm{mg} / \mathrm{L}$ respectively. For the dormant season, the upstream and downstream median was $165.8 \mathrm{mg} / \mathrm{L}$ and $171.2 \mathrm{mg} / \mathrm{L}$ respectively. The results of the Mann-Whitney Rank Sum test indicated that there was not a statistically significant difference in upstream vs. downstream concentration during either the growing $(p=0.839)$ or dormant $(p=0.493)$ season. The median upstream concentration in the growing season was statistically different $(p<0.001)$ from the median value measured during the dormant season. The median downstream concentration. in the growing season was statistically different $(p<0.001)$ from the median value measured during the dormant season (Table 10). 


\section{CHAPTER IV: DISCUSSION}

\section{Absence of Metals}

Each of the metals analyzed (Al, As, Be, Cd, Cr, Cu, Mn, Se, Pb, and $\mathrm{Zn}$ ), were BDL of the ICP-OES. Thus, the concentrations for $\mathrm{Cu}, \mathrm{Pb}$, and $\mathrm{Zn}$ detected in this study were lower than what was found by Komínková et al. (2016) at combined sewage overflow sites, which implies that the four CSO locations on the canal are not significantly contributing to heavy metal contamination. In addition, with each of the heavy metals having concentrations, the concentrations of $\mathrm{Al}, \mathrm{As}, \mathrm{Be}, \mathrm{Cd}, \mathrm{Cr}, \mathrm{Cu}, \mathrm{Mn}, \mathrm{Se}, \mathrm{Pb}$, and $\mathrm{Zn}$ were below the surface water levels determined by the World Health Organization. The absence of such metals in the Chicago River could be influenced by the chemistry of the river itself, the chemistry of the individual metals, or the surface area and surface charge of sediments in the river. The World Health Organization has collected data on heavy metal concentrations from surface waters across the world and determined the levels of $\mathrm{Al}, \mathrm{As} \mathrm{Be}, \mathrm{Cd}, \mathrm{Cr}, \mathrm{Cu}, \mathrm{Mn}, \mathrm{Se}$, and $\mathrm{Zn}$ to be on the microgram scale. In the neutral to alkaline waters of the Chicago River, the solubility of metals such as $\mathrm{Al}, \mathrm{As}, \mathrm{Be}, \mathrm{Cd}, \mathrm{Cr}, \mathrm{Cu}, \mathrm{Pb}, \mathrm{Mn}, \mathrm{Se}$, and $\mathrm{Zn}$ is low. These metals may precipitate onto either sediments or suspended particles in the water (Garbarino et al., 1995) which could help to explain the absence of such metals in the water.

In nature, aluminum is most abundant as insoluble aluminum oxide $\left(K_{\mathrm{sp}}=1.9 \times 10^{-33}\right)$

present in water via the reaction $\left(2 \mathrm{Al}_{2} \mathrm{O}_{3}+6 \mathrm{H}^{+}->\mathrm{Al}^{3+}+3 \mathrm{H}_{2} \mathrm{O}\right)$. Although no $\mathrm{Al}$ was detected in this study, dissolved Al concentrations typically range from $1 \mu \mathrm{g} / \mathrm{L}$ to $50 \mu \mathrm{g} / \mathrm{L}$ (World Health Organization, 2010). The CMWRD did not determine Al levels in the North and South Branches of the Chicago River and direct comparisons cannot be made (Table 2, Table 3). With a detection 
limit of $1.0 \mu \mathrm{g} / \mathrm{L}$, it is possible that similar concentrations to those determined by the World Health Organization in 2010 were present but unable to be detected in this study.

Arsenic is mainly present as $\mathrm{H}_{3} \mathrm{AsO}_{4}$ derived from the chemical reaction $\left(\mathrm{As}_{2} \mathrm{~S}_{3}+6 \mathrm{H}_{2} \mathrm{O}-\right.$ $>2 \mathrm{H}_{3} \mathrm{AsO}_{3}+3 \mathrm{H}_{2} \mathrm{~S}$ ) and will undergo either adsorption onto suspended sediment or precipitate with aluminum hydroxides, iron(III), and manganese oxyhydroxides (Magalhães, 2002). This causes the accumulation of As in sediments and in water it is generally found in concentrations ranging from $1 \mu \mathrm{g} / \mathrm{L}$ to $2 \mu \mathrm{g} / \mathrm{L}$. (World Health Organization, 2010). The CMWRD determined As levels in the North and South Branches of the Chicago River to range from $0.1 \mu \mathrm{g} / \mathrm{L}$ to less than $5 \mu \mathrm{g} / \mathrm{L}$ (Table 2, Table 3). With a detection limit of $1.0 \mu \mathrm{g} / \mathrm{L}$, it is possible that similar concentrations were present but unable to be detected in this study.

Be commonly occurs as beryllium oxide $(\mathrm{BeO})$ and, upon contacting water, reacts to form beryllium hydroxide $\left(\mathrm{Be}\left(\mathrm{OH}_{2}\right)\right.$ which has a low solubility $\left(K_{\mathrm{sp}}==6.92 \times 10^{-22}\right)$ in alkaline waters (ROPP 2013). The low solubility of Be was noted in a study of the surface water of the Great Lakes with Be concentrations ranging from less than $0.004 \mu \mathrm{g} / \mathrm{L}$ to $0.12 \mu \mathrm{g} / \mathrm{L}$ (World Health Organization, 2014). The CMWRD did not determine Be levels in the North and South Branches of the Chicago River and direct comparisons cannot be made (Table 2, Table 3). As the detection limit for Be was $0.09 \mu \mathrm{g} / \mathrm{L}$, it is possible that similar concentrations were present but unable to be detected in this study.

Cd is known to form insoluble compounds with a heavy metal such as arsenic, magnesium, calcium, strontium, barium, and radium (ROPP 2013). In surface waters, $\mathrm{Cd}$ concentrations are commonly below $1 \mu \mathrm{g} / \mathrm{L}$ and median concentrations of 110 stations throughout the world detected $<1 \mu \mathrm{g} / \mathrm{L}$ of $\mathrm{Cd}$ in waters. For example, the Rhine and Danube canal in 1988 experienced levels of Cd in surface water ranging from $0.02 \mu \mathrm{g} / \mathrm{L}$ to $0.3 \mu \mathrm{g} / \mathrm{L}$ 
(World Health Organization, 2011). The CMWRD determined Cd levels in the North and South Branches of the Chicago River to range from less than $0.1 \mu \mathrm{g} / \mathrm{L}$ to less than $0.5 \mu \mathrm{g} / \mathrm{L}$ (Table 2, Table 3). As the detection limit for $\mathrm{Cd}$ was $0.1 \mu \mathrm{g} / \mathrm{L}$, it is possible that similar concentrations were present but unable to be detected in this study.

In waters, dissolved $\mathrm{Cr}$ is present in low amounts as insoluble $\mathrm{Cr}(\mathrm{OH})_{3}\left(K_{\mathrm{sp}}==6.3 \times 10^{-}\right.$ $\left.{ }^{31}\right)$. The average concentration of $\mathrm{Cr}$ in surface waters is $0.5 \mu \mathrm{g} / \mathrm{L}$ to $2 \mu \mathrm{g} / \mathrm{L}$ with dissolved $\mathrm{Cr}$ concentrations ranging from $0.02 \mu \mathrm{g} / \mathrm{L}$ to $0.3 \mu \mathrm{g} / \mathrm{L}$ and levels increasing up to $84 \mu \mathrm{g} / \mathrm{L}$ in highly industrial areas (World Health Organization, 1996). The CMWRD determined Cr levels in the North and South Branches of the Chicago River to range from less than $0.3 \mu \mathrm{g} / \mathrm{L}$ to less than 0.5 $\mu \mathrm{g} / \mathrm{L}$ (Table 2, Table 3). As the detection limit for $\mathrm{Cr}$ was $0.2 \mu \mathrm{g} / \mathrm{L}$, it is possible that similar concentrations were present but unable to be detected in this study.

$\mathrm{Cu}$ will remain insoluble at the $\mathrm{pH}$ and temperature ranges of Chicago River water (ROPP 2013), and the concentrations of $\mathrm{Cu}$ in surface water can vary from $0.05 \mu \mathrm{g} / \mathrm{L}$ to $1 \mathrm{mg} / \mathrm{L}$ with a median value of $0.01 \mathrm{mg} / \mathrm{L}$ in the United States (World Health Organization, 2004). The CMWRD determined Cu levels in the North and South Branches of the Chicago River to range from less than $0.2 \mu \mathrm{g} / \mathrm{L}$ to $0.6 \mu \mathrm{g} / \mathrm{L}$ (Table 2, Table 3). As the detection limit for $\mathrm{Cu}$ was 0.4 $\mu \mathrm{g} / \mathrm{L}$, it is possible that similar concentrations were present but unable to be detected in this study.

$\mathrm{Pb}$ has a low solubility in neutral to alkaline river waters and levels typically range from $3 \mu \mathrm{g} / \mathrm{L}$ to $30 \mu \mathrm{g} / \mathrm{L}$ (World Health Organization, 2011). The CMWRD determined Pb levels in the North and South Branches of the Chicago River to range from less than $0.2 \mu \mathrm{g} / \mathrm{L}$ to $3 \mu \mathrm{g} / \mathrm{L}$ (Table 2, Table 3). As the detection limit for $\mathrm{Pb}$ was $1 \mu \mathrm{g} / \mathrm{L}$, it is possible that similar concentrations were present but unable to be detected in this study. 
For Se, levels in surface water can range from $0.06 \mu \mathrm{g} / \mathrm{L}$ to $4 \mathrm{mg} / \mathrm{L}$ with concentrations increasing as $\mathrm{pH}$ decreases due to the formation of soluble selenite compounds (World Health Organization, 2011). The CMWRD determined Se levels in the North and South Branches of the Chicago River to range from less than $0.3 \mu \mathrm{g} / \mathrm{L}$ to less than $5 \mu \mathrm{g} / \mathrm{L}$ (Table 2, Table 3). Similar to the metals discussed above, with a detection limit of $2 \mu \mathrm{g} / \mathrm{L}$ it is possible that similar concentrations were present but unable to be detected in this study.

The concentrations of the heavy metals $\mathrm{Al}, \mathrm{As}, \mathrm{Cd} . \mathrm{Cr}, \mathrm{Cu}, \mathrm{Pb}$, and $\mathrm{Se}$ detected in this study were similar to the concentrations detected by the World Health Organization and CMWRD in surface waters. However, such similarities were not present for $\mathrm{Mn}, \mathrm{Pb}$, and $\mathrm{Zn}$. In surface waters worldwide, levels of Mn typically range from $1 \mu \mathrm{g} / \mathrm{L}$ to $200 \mu \mathrm{g} / \mathrm{L}$ with median concentrations of around $16 \mu \mathrm{g} / \mathrm{L}$ (World Health Organization, 2011). The CMWRD determined Mn levels in the North and South Branches of the Chicago River to range from $4 \mu \mathrm{g} / \mathrm{L}$ to $1 \mu \mathrm{g} / \mathrm{L}$ (Table 2, Table 3). Based on these ranges and the detection limit of $0.1 \mu \mathrm{g} / \mathrm{L}$, it is expected that measurable amounts of Mn should be present in the Chicago River water. However, this is not what was found in this study. $\mathrm{Zn}$ is naturally present in water and concentrations typically range from $5 \mu \mathrm{g} / \mathrm{L}$ to $10 \mu \mathrm{g} / \mathrm{L}$ with some concentrations reaching up to $1.0 \mathrm{mg} / \mathrm{L}$ (World Health Organization, 2003). The CMWRD determined Zn levels in the North and South Branches of the Chicago River to range from less than $10 \mu \mathrm{g} / \mathrm{L}$ to $1 \mu \mathrm{g} / \mathrm{L}$ (Table 2, Table 3). Based these ranges and that detection limit of $0.2 \mu \mathrm{g} / \mathrm{L}$, it is expected that measurable amounts of $\mathrm{Zn}$ should be present in the Chicago River water. However, this is not what was found in this study with levels unable to be determined. The lack of detection of $\mathrm{Mn}$ and $\mathrm{Zn}$ in this study could be caused by errors discussed in the potential error section. 


\section{Chloride Interaction with Metals}

Chloride concentrations at the study site did not experience significant changes upstream or downstream during either season. However, seasonal differences were detected with the concentration increasing from $117.9 \mathrm{mg} / \mathrm{L}$ to $124.8 \mathrm{mg} / \mathrm{L}$ in the growing season to $165.8 \mathrm{mg} / \mathrm{L}$ to $171.2 \mathrm{mg} / \mathrm{L}$ in the dormant season. Snow events and freezing temperatures occurred during the week of November 5, 2019 and road salt application took place throughout the city, contributing to the seasonal $\mathrm{Cl}^{-}$changes. While it is expected that the increase in $\mathrm{Cl}^{-}$concentrations seasonally would lead to an increase in the mobilization of the heavy metals by inducing ion exchange and causing colloid dispersion (Bäckström et al., 2004; Norrström, 2005; Nelson et al., 2009; Acosta et al., 2011; Huber et al., 2016), this was not able to be determined due to the lack of heavy metal detection in the water samples.

\section{Role of Gardens}

This study did not provide an indication on the effectiveness of the floating gardens to alter the water quality of the Chicago River as no heavy metals were detected in the waters. However, if metals were to have been detected, potential removal by wetlands could be caused by chemical, physical, and biological processes, which include adsorption to sediments and organic matter, absorption and biogeochemical changes in plant and bacteria cycles, and deposition of suspended solids (Sinicrope et al., 1992; Sheoran and Sheoran, 2006; Marchand et

al., 2010). With a surface area of approximately $90 \mathrm{~m}^{2}$, the floating gardens have a high potential for biofilm growth, which may influence metal removal in the waters. Algae was present in visual observations during each sampling event and is a possible uncontrolled mechanism for metal removal. 
Plant uptake and biologic processes are an important means for heavy metal removal in wetlands and could potentially cause reduced heavy metal concentrations in the river. In floating wetland plants, the roots serve as the primary pathway for metal removal. Although the rate of heavy metal removal varies greatly depending on plant growth and metal concentration, the uptake per unit area is highest for herbaceous plants such as those in the floating gardens. This uptake by plants is a passive movement that involves the exchange of cations through the cell wall and the absorption to anionic sites (Briggs and Lundegardh, 1957; Sheoran and Sheoran, 2006). The absorption onto anionic sites in cell walls allows for wetland plant tissues accumulate greater heavy metal concentrations than the surrounding environment. However, the bioaccumulation of heavy metals within plants was not in the scope of this study and was not examined.

\section{Study Limitations and Future Directions}

A significant limitation in this study is the size of the gardens compared to the size of the Chicago River. As the gardens only stretch over a fraction of the river, they have a small area of influence and are unlikely to affect the chemistry of the waters that are not in direct contact with the gardens. In addition, by only collecting surface water samples and not collecting plant samples it is possible that additional processes are occurring that were not detected. While the large variety of plants on the floating gardens serve to provide resources for aquatic organisms, it is possible that a monocultural system of a metal removing plant such as Phragmites australis would lead to greater results.

This study could be expanded in the future by performing a sediment analysis of the riverbed to determine heavy metal concentration in the sediments. The results of such an analysis could provide the heavy metal concentration in the sediment and support the idea that the heavy 
metals are not suspended in the water column at measurable levels and are instead precipitating onto the riverbed. In addition, it would be beneficial to determine heavy metal content of the plants in the floating gardens by using an ICP-OES. This would provide additional insight on the absorption of the heavy metals onto the biofilms and roots of the plants and hep to explain the lack of metals in the water.

\section{Potential Error}

The transport of the heavy metal samples may have led to potential error in the heavy metal concentrations. Due to the two-hour transport time from Chicago, IL to Illinois State University in Normal, IL, the heavy metals samples were not able to be immediately frozen upon collection. In addition, potential error may have occurred in the development of the diluted standard solutions and the development of the calibration curves used for determining the concentrations of the heavy metals. 


\section{CHAPTER V: CONCLUSION}

Heavy metal contamination can have severe impacts on aquatic ecosystems around the world. Wetlands and floating gardens can help reduce heavy metal concentrations by promoting processes such as sedimentation, adsorption, and biologic uptake. While many studies have shown that wetlands may have success in reducing heavy metal concentrations, there is limited information available on the role of floating gardens in an uncontrolled river system. The results of this study show that the heavy metal ( $\mathrm{As}, \mathrm{Cd}, \mathrm{Cr}, \mathrm{Cu}, \mathrm{Fe}, \mathrm{Pb}, \mathrm{Mn}, \mathrm{Se}$, and $\mathrm{Zn}$ ) concentrations in the Chicago River are at non-concerning levels. While it was unable to be determined if the floating gardens were effective in reducing the concentrations of heavy metals, it is possible that if heavy metals were present such removal would occur. This study is useful in understanding the heavy metal concentrations in the Chicago River and could serve to support studies on changing concentrations in the river. 


\section{REFERERNCES}

Acosta, J.A., Jansen, B., Kalbitz, K., Faz, A., and Martínez-Martínez, S., 2011, Salinity increases mobility of heavy metals in soils: Chemosphere, v. 85, p. 1318-1324, doi:10.1016/j.chemosphere.2011.07.046.

Adriano, D.C., 1986, Trace elements in the terrestrial environment.:, doi:10.2134/jeq1987.00472425001600010030x.

Ali, H., Khan, E., and Sajad, M.A., 2013, Phytoremediation of heavy metals-Concepts and applications: Chemosphere, v. 91, p. 869-881, doi:10.1016/j.chemosphere.2013.01.075.

Bäckström, M., Karlsson, S., Bäckman, L., Folkeson, L., and Lind, B., 2004, Mobilisation of heavy metals by deicing salts in a roadside environment: Water Research, v. 38, p. 720732, doi:10.1016/j.watres.2003.11.006.

Beringer, M., Drexler, J., Fisher, N., Henninsen, R., and McGeer, J., 2007, Framework for Metals Risk Assessment: EPA, v. 120.

Bradl, H.B., 2005, Heavy Metals in the Environment: Interface Science and Technology, v. 6.

Briggs, B.G.E., and Lundegardh, R., 1957, Apparent Free Space: Division of Food Preservation and Transport, C.S.I.R.O, p. 11-30.

Cao, W., and Zhang, Y., 2014, Removal of nitrogen (N) from hypereutrophic waters by ecological floating beds (EFBs) with various substrates: Ecological Engineering, doi:10.1016/j.ecoleng.2013.10.018.

Chen, L., Zhou, S., Shi, Y., Wang, C., Li, B., Li, Y., and Wu, S., 2018, Heavy metals in food crops, soil, and water in the Lihe River Watershed of the Taihu Region and their potential health risks when ingested: Science of the Total Environment, v. 615, p. 141-149, doi:10.1016/j.scitotenv.2017.09.230. 
Corsi, S.R., Graczyk, D.J., Geis, S.W., Booth, N.L., and Richards, K.D., 2010, A fresh look at road salt: Aquatic toxicity and water-quality impacts on local, regional, and national scales: Environmental Science and Technology, v. 44, p. 7376-7382, doi:10.1021/es101333u.

EPA, 2009, National Primary Drinking Water Guidelines: v. EPA 816-F-, p. 7, https://www.epa.gov/sites/production/files/2016-06/documents/npwdr_complete_table.pdf.

Galal, T.M., Farahat, E.A., El-Midany, M.M., and Hassan, L.M., 2016, Nutrients and heavy metals accumulation by the giant milkweed Calotropis procera (Aiton) W.T. Aiton in urbanized areas, Egypt: Rendiconti Lincei, v. 27, p. 241-250, doi:10.1007/s12210-0150468-4.

Headley, T.R., and Tanner, C.C., 2012, Constructed wetlands with floating emergent macrophytes: An innovative stormwater treatment technology: Critical Reviews in Environmental Science and Technology, v. 42, p. 2261-2310, doi:10.1080/10643389.2011.574108.

Headley, T.R., and Tanner, C.C., 2008, Floating Treatment Wetlands: an Innovative Option for Stormwater Quality Applications: 11th International Conference on Wetland Systems for Water Pollution Control, v. 1, p. 1101-1106, doi:10.1016/0014-4886(91)90023-6.

Hnat'uková, P., Benesova, L., and Komfnkova, D., 2009, Impact of urban drainage on metal distribution in sediments of urban streams: Water Science and Technology, v. 59, p. 12371246, doi:10.2166/wst.2009.091.

Huber, M., Hilbig, H., Badenberg, S.C., Fassnacht, J., Drewes, J.E., and Helmreich, B., 2016, Heavy metal removal mechanisms of sorptive filter materials for road runoff treatment and remobilization under de-icing salt applications: Water Research, v. 102, p. 453-463, doi:10.1016/j.watres.2016.06.063. 
Jaishankar, M., Tseten, T., Anbalagan, N., Mathew, B.B., and Beeregowda, K.N., 2014, Toxicity, mechanism and health effects of some heavy metals: Interdisciplinary Toxicology, v. 7, p. 60-72, doi:10.2478/intox-2014-0009.

Kelly, W.R., Panno, S. V., and Hackley, K.C., 2012, Impacts of road salt runoff on water quality of the Chicago, Illinois, region: Environmental and Engineering Geoscience, v. 18, p. 6581, doi:10.2113/gseegeosci.18.1.65.

Kerr-Upal, M., Seasons, M., and Mulamoottil, G., 2000, Retrofitting a stormwater management facility with a wetland component: Journal of Environmental Science and Health - Part A Toxic/Hazardous Substances and Environmental Engineering, v. 35, p. 1289-1307, doi:10.1080/10934520009377037.

Khan, M.A., Ahmad, I., and Ur Rahman, I., 2007, Effect of environmental pollution on heavy metals content of Withania somnifera: Journal of the Chinese Chemical Society, v. 54, p. 339-343, doi:10.1002/jccs.200700049.

Kobielska, P.A., Howarth, A.J., Farha, O.K., and Nayak, S., 2018, Metal-organic frameworks for heavy metal removal from water: Coordination Chemistry Reviews, v. 358, p. 92-107, doi:10.1016/j.ccr.2017.12.010.

Lee, B.H., and Scholz, M., 2007, What is the role of Phragmites australis in experimental constructed wetland filters treating urban runoff? Ecological Engineering, v. 29, p. 87-95, doi:10.1016/j.ecoleng.2006.08.001.

Li, X.N., Song, H.L., Li, W., Lu, X.W., and Nishimura, O., 2010, An integrated ecological floating-bed employing plant, freshwater clam and biofilm carrier for purification of eutrophic water: Ecological Engineering, v. 36, p. 382-390, doi:10.1016/j.ecoleng.2009.11.004. 
Lu, Y., Liang, X., Niyungeko, C., Zhou, J., Xu, J., and Tian, G., 2018, A review of the identification and detection of heavy metal ions in the environment by voltammetry: Talanta, v. 178, p. 324-338, doi:10.1016/j.talanta.2017.08.033.

Magalhães, M.C.F., 2002, Arsenic. An environmental problem limited by solubility: Pure and Applied Chemistry, v. 74, p. 1843-1850, doi:10.1351/pac200274101843.

Marchand, L., Mench, M., Jacob, D.L., and Otte, M.L., 2010, Metal and metalloid removal in constructed wetlands, with emphasis on the importance of plants and standardized measurements: A review: Environmental Pollution, v. 158, p. 3447-3461, doi:10.1016/j.envpol.2010.08.018.

McAndrew, B., and Ahn, C., 2017, Developing an ecosystem model of a floating wetland for water quality improvement on a stormwater pond: Journal of Environmental Management, v. 202, p. 198-207, doi:10.1016/j.jenvman.2017.07.035.

Nealson, K.H., and Myers, C.R., 1992, Microbial reduction of manganese and iron: New approaches to carbon cycling: Applied and Environmental Microbiology, v. 58, p. 439-443, doi:10.1128/aem.58.2.439-443.1992.

Nelson, S.S., Yonge, D.R., and Barber, M.E., 2009, Effects of Road Salts on Heavy Metal Mobility in Two Eastern Washington Soils: Journal of Environmental Engineering-Asce, v. 135, p. 505-510, doi:10.1061/(ASCE)0733-9372(2009)135:7(505).

Norrström, A.C., 2005, Metal mobility by de-icing salt from an infiltration trench for highway runoff: Applied Geochemistry, v. 20, p. 1907-1919, doi:10.1016/j.apgeochem.2005.06.002.

Paalman, M.A.A., Van Der Weijden, C.H., and Loch, J.P.G., 1994, Sorption of cadmium on suspended matter under estuarine conditions; competition and complexation with major seawater ions: Water, Air, \& Soil Pollution, v. 73, p. 49-60, doi:10.1007/BF00477975. 
Paterson, S., Mackay, D., Tam, D., and Shiu, W.Y., 1990, Uptake of organic chemicals by plants: A review of processes, correlations and models: Chemosphere, v. 21, p. 297-331, doi:10.1016/0045-6535(90)90002-B.

Ropp, R.C. Encyclopedia of the Alkaline Earth Compounds. Elsevier, 2013.

Salem, H.., Eweida, E.., and Faraq, A., 2000, Heavy Metals in Drinking Water and Their Environmental Impact on Human Health: Cairo University, p. 542-556, doi:10.1016/j.chb.2015.04.031.

Schnoor, J.L., Licht, L.A., McCutcheon, S.C., Wolfe, N.L., and Carreira, L.H., 1995, Phytoremediation of Organic and Nutrient Contaminants: Environmental Science and Technology, v. 29, p. 318-323, doi:10.1021/es00007a002.

Shah, A., 2017, Heavy Metal Impact on Aquatic Life and Human Health - an Over View: IAIA17 Conference Proceedings, http://conferences.iaia.org/2017/final-papers/Shah, Alkesh - Heavy Metal Impacto on Aquatic Life and Human Health.pdf.

Sheoran, A.S., and Sheoran, V., 2006, Heavy metal removal mechanism of acid mine drainage in wetlands: A critical review: Minerals Engineering, v. 19, p. 105-116, doi:10.1016/j.mineng.2005.08.006.

Shimp, J.F., Tracy, J.C., Davis, L.C., Lee, E., Huang, W., Erickson, L.E., and Schnoor, J.L., 1993, Beneficial Effects of Plants in the Remediation of Soil and Groundwater Contaminated with Organic Materials: Critical Reviews in Environmental Science and Technology, v. 23, p. 41-77, doi:10.1080/10643389309388441.

Simonich, S.L., and Hites, R.A., 1995, Organic Pollutant Accumulation in Vegetation: Environmental Science and Technology, v. 29, p. 2905-2914, doi:10.1021/es00012a004. 
Singh, A., and Kumar, Y., 2017, Phytoremediation: Cleaning Environment Using Plants: Trends in Plant Science, p. 100-111, https://www.researchgate.net/profile/Arvinder_Singh4/publication/322224358_Phytoremedi ation_Cleaning_Environment_Using_Plants/links/5a4cf7fa458515a6bc6dabea/Phytoremedi ation-Cleaning-Environment-Using-Plants.pdf.

Sinicrope, T.L., Langis, R., Gersberg, R.M., Busnardo, M.J., and Zedler, J.B., 1992, Metal removal by wetland mesocosms subjected to different hydroperiods: Ecological Engineering, v. 1, p. 309-322, doi:10.1016/0925-8574(92)90013-R.

Susarla, S., Medina, V.F., and McCutcheon, S.C., 2002, Phytoremediation: An ecological solution to organic chemical contamination: Ecological Engineering, v. 18, p. 647-658, doi:10.1016/S0925-8574(02)00026-5.

Tao, W., Bays, J.S., Meyer, D., Smardon, R.C., and Levy, Z.F., 2014, Constructed wetlands for treatment of combined sewer overflow in the US: A review of design challenges and application status: Water (Switzerland), v. 6, p. 3362-3385, doi:10.3390/w6113362.

Trujillo-González, J.M., Torres-Mora, M.A., Keesstra, S., Brevik, E.C., and Jiménez-Ballesta, R., 2016, Heavy metal accumulation related to population density in road dust samples taken from urban sites under different land uses: Science of the Total Environment, v. 553, p. 636-642, doi:10.1016/j.scitotenv.2016.02.101.

Vaze, J., and Chiew, F.H.S., 2002, Experimental study of pollutant accumulation on an urban road surface: Urban Water, v. 4, p. 379-389, doi:10.1016/S1462-0758(02)00027-4.

Wang, C.Y., and Sample, D.J., 2014, Assessment of the nutrient removal effectiveness of floating treatment wetlands applied to urban retention ponds: Journal of Environmental Management, v. 137, p. 23-35, doi:10.1016/j.jenvman.2014.02.008. 
Wang, W.H., Wang, Y., Li, Z., Wei, C.Z., Zhao, J.C., and Sun, L. qin, 2018, Effect of a strengthened ecological floating bed on the purification of urban landscape water supplied with reclaimed water: Science of the Total Environment, v. 622-623, p. 1630-1639, doi:10.1016/j.scitotenv.2017.10.035.

World Health Organization, 2010, Aluminium in drinking-water, Background document for development of WHO: Guidelines for drinking-water quality,.

World Health Organization, 2010, Arsenic in drinking-water, Background document for development of WHO: Guidelines for drinking-water quality, WHO/SDE/WSH/03.04/75/rev1.

World Health Organization, 2014, Beryllium in Drinking Water: Guidelines for drinking-water quality, p. 13-16.

World Health Organization, 2011, Cadmium in Drinking Water: Guidelines for drinking-water quality, WHO/SDE/WSH/03.04/80/Rev/1.

World Health Organization, 1996, Chromium in Drinking Water: WHO/SDE/WSH/03.04/04.

World Health Organization, 2004, Copper in Drinking Water: v WHO/SDE/WSH/03.04/88.

World Health Organization, 2011, Lead in Drinking Water: v WHO/SDE/WSH/03.04/09/Rev/1. World Health Organization, 2011, Manganese in Drinking-water: Guidelines for drinking-water quality, WHO/SDE/WSH/03.04/104/Rev/1.

World Health Organization, 2011, Selenium in Drinking Water: WHO/HSE/WSH/10.01/14.

World Health Organization, 2003, Zinc in drinking water: Guidelines for drinking-water quality, v. 2, doi:10.1021/ja02131a016 WHO/SDE/WSH/03.04/17. 
Wuana, R.A., and Okieimen, F.E., 2011, Heavy Metals in Contaminated Soils: A Review of Sources, Chemistry, Risks and Best Available Strategies for Remediation: ISRN Ecology, v. 2011, p. 1-20, doi:10.5402/2011/402647.

Zhao, F., Xi, S., Yang, X., Yang, W., Li, J., Gu, B., and He, Z., 2012, Purifying eutrophic river waters with integrated floating island systems: Ecological Engineering, v. 40, p. 53-60, doi:10.1016/j.ecoleng.2011.12.012. 
APPENDIX A: HEAVY METAL CONCENTRATIONS

\begin{tabular}{|c|c|c|c|c|c|c|c|c|c|c|}
\hline Sample & Al & As & Be & Cd & $\mathrm{Cr}$ & $\mathrm{Cu}$ & Mn & Se & $\mathbf{P b}$ & $\mathbf{Z n}$ \\
\hline $\begin{array}{c}\text { US }=\text { Upstream } \\
\text { DS }=\text { Downstream } \\
\text { BDL: Below Detection Limit }\end{array}$ & $\mu g / L$ & $\mu g / L$ & $\mu g / L$ & $\mu \mathrm{g} / \mathrm{L}$ & $\mu \mathrm{g} / \mathrm{L}$ & $\mu g / L$ & $\mu g / L$ & $\mu \mathrm{g} / \mathrm{L}$ & $\mu g / L$ & $\mu \mathrm{g} / \mathrm{L}$ \\
\hline US-7-6-19 & BDL & BDL & BDL & BDL & BDL & BDL & BDL & BDL & BDL & BDL \\
\hline US-7-6-19 & BDL & BDL & BDL & BDL & $\mathrm{BDL}$ & BDL & BDL & BDL & BDL & BDL \\
\hline US-7-6-19 & BDL & BDL & BDL & BDL & BDL & BDL & $\mathrm{BDL}$ & BDL & BDL & BDL \\
\hline US-7-6-19 & BDL & BDL & BDL & BDL & BDL & BDL & BDL & BDL & BDL & BDL \\
\hline US-7-6-19 & BDL & $\mathrm{BDL}$ & $\mathrm{BDL}$ & BDL & BDL & BDL & $\mathrm{BDL}$ & $\mathrm{BDL}$ & BDL & $\mathrm{BDL}$ \\
\hline US-7-6-19 & BDL & $\mathrm{BDL}$ & $\mathrm{BDL}$ & BDL & BDL & BDL & BDL & BDL & BDL & BDL \\
\hline US-7-6-19 & BDL & BDL & BDL & BDL & BDL & BDL & BDL & BDL & BDL & BDL \\
\hline US-7-6-19 & BDL & BDL & BDL & BDL & BDL & BDL & BDL & BDL & BDL & BDL \\
\hline US-7-6-19 & BDL & BDL & BDL & BDL & BDL & BDL & BDL & BDL & BDL & BDL \\
\hline US-7-6-19 & BDL & BDL & BDL & $\mathrm{BDL}$ & $\mathrm{BDL}$ & BDL & BDL & BDL & BDL & $\mathrm{BDL}$ \\
\hline DS-7-6-19 & BDL & BDL & BDL & BDL & BDL & BDL & BDL & $\mathrm{BDL}$ & BDL & $\mathrm{BDL}$ \\
\hline DS-7-6-19 & $\mathrm{BDL}$ & BDL & $\mathrm{BDL}$ & $\mathrm{BDL}$ & BDL & $\mathrm{BDL}$ & $\mathrm{BDL}$ & $\mathrm{BDL}$ & BDL & BDL \\
\hline DS-7-6-19 & BDL & BDL & BDL & BDL & BDL & BDL & BDL & BDL & BDL & $\mathrm{BDL}$ \\
\hline DS-7-6-19 & BDL & BDL & $\mathrm{BDL}$ & BDL & BDL & BDL & BDL & BDL & BDL & $\mathrm{BDL}$ \\
\hline DS-7-6-19 & BDL & BDL & BDL & BDL & BDL & BDL & BDL & BDL & BDL & $\mathrm{BDL}$ \\
\hline DS-7-6-19 & BDL & BDL & BDL & BDL & BDL & BDL & BDL & BDL & BDL & BDL \\
\hline DS-7-6-19 & BDL & BDL & BDL & BDL & BDL & BDL & BDL & BDL & BDL & $\mathrm{BDL}$ \\
\hline DS-7-6-19 & BDL & BDL & BDL & BDL & $\mathrm{BDL}$ & BDL & BDL & BDL & BDL & $\mathrm{BDL}$ \\
\hline DS-7-6-19 & BDL & BDL & BDL & BDL & $\mathrm{BDL}$ & BDL & BDL & BDL & BDL & BDL \\
\hline DS-7-6-19 & BDL & BDL & BDL & BDL & BDL & BDL & BDL & BDL & BDL & BDL \\
\hline US-7-8-19 & BDL & BDL & BDL & BDL & BDL & BDL & BDL & BDL & BDL & BDL \\
\hline US-7-8-19 & BDL & BDL & BDL & BDL & BDL & BDL & BDL & BDL & BDL & $\mathrm{BDL}$ \\
\hline US-7-8-19 & BDL & $\mathrm{BDL}$ & BDL & BDL & BDL & $\mathrm{BDL}$ & BDL & BDL & BDL & BDL \\
\hline US-7-8-19 & BDL & BDL & BDL & BDL & BDL & BDL & BDL & BDL & BDL & BDL \\
\hline US-7-8-19 & BDL & BDL & BDL & BDL & BDL & $\mathrm{BDL}$ & $\mathrm{BDL}$ & BDL & BDL & $\mathrm{BDL}$ \\
\hline US-7-8-19 & BDL & BDL & BDL & BDL & BDL & BDL & BDL & BDL & BDL & BDL \\
\hline US-7-8-19 & BDL & $\mathrm{BDL}$ & $\mathrm{BDL}$ & BDL & BDL & $\mathrm{BDL}$ & BDL & BDL & BDL & BDL \\
\hline US-7-8-19 & BDL & BDL & BDL & BDL & BDL & BDL & BDL & BDL & BDL & BDL \\
\hline US-7-8-19 & BDL & BDL & BDL & BDL & $\mathrm{BDL}$ & $\mathrm{BDL}$ & BDL & BDL & BDL & $\mathrm{BDL}$ \\
\hline US-7-8-19 & BDL & BDL & BDL & BDL & BDL & BDL & BDL & BDL & BDL & BDL \\
\hline DS-7-8-19 & BDL & BDL & BDL & BDL & BDL & BDL & BDL & BDL & BDL & BDL \\
\hline DS-7-8-19 & BDL & BDL & BDL & BDL & BDL & BDL & BDL & BDL & BDL & BDL \\
\hline DS-7-8-19 & $\mathrm{BDL}$ & BDL & BDL & $\mathrm{BDL}$ & BDL & $\mathrm{BDL}$ & BDL & BDL & BDL & BDL \\
\hline DS-7-8-19 & BDL & BDL & BDL & BDL & BDL & BDL & BDL & BDL & BDL & BDL \\
\hline DS-7-8-19 & $\mathrm{BDL}$ & $\mathrm{BDL}$ & $\mathrm{BDL}$ & $\mathrm{BDL}$ & $\mathrm{BDL}$ & $\mathrm{BDL}$ & $\mathrm{BDL}$ & BDL & $\mathrm{BDL}$ & $\mathrm{BDL}$ \\
\hline DS-7-8-19 & BDL & BDL & BDL & BDL & BDL & BDL & BDL & BDL & BDL & $\mathrm{BDL}$ \\
\hline
\end{tabular}




\begin{tabular}{|c|c|c|c|c|c|c|c|c|c|c|}
\hline DS-7-8-19 & BDL & BDL & BDL & BDL & BDL & BDL & BDL & BDL & BDL & BDL \\
\hline DS-7-8-19 & BDL & BDL & BDL & BDL & BDL & BDL & BDL & BDL & BDL & $\mathrm{BDL}$ \\
\hline DS-7-8-19 & BDL & BDL & BDL & BDL & $\mathrm{BDL}$ & BDL & BDL & BDL & BDL & $\mathrm{BDL}$ \\
\hline DS-7-8-19 & BDL & BDL & BDL & BDL & BDL & BDL & BDL & BDL & BDL & $\mathrm{BDL}$ \\
\hline US-7-30-19 & BDL & $\mathrm{BDL}$ & BDL & BDL & BDL & BDL & BDL & BDL & BDL & BDL \\
\hline US-7-30-19 & BDL & BDL & BDL & BDL & BDL & BDL & BDL & BDL & BDL & BDL \\
\hline US-7-30-19 & BDL & BDL & $\mathrm{BDL}$ & BDL & BDL & BDL & BDL & BDL & BDL & BDL \\
\hline US-7-30-19 & BDL & BDL & BDL & BDL & BDL & BDL & BDL & BDL & BDL & BDL \\
\hline US-7-30-19 & BDL & BDL & BDL & BDL & BDL & BDL & BDL & BDL & BDL & $\mathrm{BDL}$ \\
\hline US-7-30-19 & BDL & BDL & BDL & BDL & $\mathrm{BDL}$ & BDL & BDL & BDL & BDL & BDL \\
\hline US-7-30-19 & BDL & BDL & BDL & BDL & BDL & BDL & BDL & BDL & BDL & BDL \\
\hline US-7-30-19 & BDL & BDL & BDL & BDL & $\mathrm{BDL}$ & BDL & BDL & BDL & BDL & BDL \\
\hline US-7-30-19 & BDL & BDL & BDL & BDL & BDL & BDL & BDL & BDL & BDL & $\overline{B D L}$ \\
\hline US-7-30-19 & BDL & BDL & BDL & BDL & $\mathrm{BDL}$ & BDL & BDL & BDL & BDL & $\mathrm{BDL}$ \\
\hline DS-7-30-19 & $\mathrm{BDL}$ & $\mathrm{BDL}$ & BDL & BDL & $\mathrm{BDL}$ & BDL & BDL & BDL & BDL & BDL \\
\hline DS-7-30-19 & BDL & BDL & BDL & BDL & BDL & BDL & BDL & BDL & BDL & BDL \\
\hline DS-7-30-19 & BDL & BDL & BDL & BDL & BDL & BDL & BDL & BDL & BDL & BDL \\
\hline DS-7-30-19 & BDL & BDL & BDL & BDL & BDL & BDL & BDL & BDL & BDL & BDL \\
\hline DS-7-30-19 & BDL & BDL & BDL & BDL & BDL & BDL & BDL & BDL & BDL & BDL \\
\hline DS-7-30-19 & BDL & BDL & BDL & BDL & $\mathrm{BDL}$ & BDL & BDL & BDL & BDL & BDL \\
\hline DS-7-30-19 & BDL & BDL & BDL & BDL & $\mathrm{BDL}$ & BDL & BDL & BDL & BDL & BDL \\
\hline DS-7-30-19 & BDL & BDL & BDL & BDL & BDL & BDL & BDL & BDL & BDL & BDL \\
\hline DS-7-30-19 & BDL & BDL & BDL & BDL & BDL & BDL & BDL & BDL & BDL & BDL \\
\hline DS-7-30-19 & BDL & BDL & BDL & BDL & BDL & BDL & BDL & BDL & BDL & $\mathrm{BDL}$ \\
\hline US-8-5-19 & BDL & BDL & BDL & BDL & BDL & BDL & BDL & BDL & BDL & $\mathrm{BDL}$ \\
\hline US-8-5-19 & $\mathrm{BDL}$ & $\mathrm{BDL}$ & $\mathrm{BDL}$ & $\mathrm{BDL}$ & $\mathrm{BDL}$ & BDL & BDL & BDL & BDL & BDL \\
\hline US-8-5-19 & BDL & BDL & BDL & BDL & BDL & BDL & BDL & BDL & BDL & BDL \\
\hline US-8-5-19 & BDL & BDL & BDL & BDL & BDL & BDL & BDL & BDL & BDL & BDL \\
\hline US-8-5-19 & BDL & BDL & BDL & BDL & BDL & BDL & BDL & BDL & BDL & BDL \\
\hline US-8-5-19 & BDL & BDL & $\mathrm{BDL}$ & BDL & BDL & BDL & BDL & BDL & BDL & BDL \\
\hline US-8-5-19 & $\mathrm{BDL}$ & $\mathrm{BDL}$ & $\mathrm{BDL}$ & $\mathrm{BDL}$ & BDL & $\mathrm{BDL}$ & $\mathrm{BDL}$ & $\mathrm{BDL}$ & $\mathrm{BDL}$ & BDL \\
\hline US-8-5-19 & $\mathrm{BDL}$ & $\mathrm{BDL}$ & $\mathrm{BDL}$ & $\mathrm{BDL}$ & BDL & $\mathrm{BDL}$ & BDL & BDL & BDL & $\overline{B D L}$ \\
\hline US-8-5-19 & BDL & BDL & $\mathrm{BDL}$ & BDL & $\mathrm{BDL}$ & BDL & BDL & BDL & BDL & BDL \\
\hline US-8-5-19 & BDL & BDL & BDL & BDL & BDL & $\mathrm{BDL}$ & $\mathrm{BDL}$ & BDL & BDL & BDL \\
\hline DS 8-5-19 & BDL & BDL & BDL & BDL & $\mathrm{BDL}$ & BDL & BDL & BDL & BDL & BDL \\
\hline DS 8-5-19 & BDL & BDL & $\mathrm{BDL}$ & BDL & BDL & BDL & BDL & BDL & BDL & BDL \\
\hline DS 8-5-19 & BDL & $\mathrm{BDL}$ & BDL & BDL & $\mathrm{BDL}$ & BDL & BDL & BDL & BDL & BDL \\
\hline DS 8-5-19 & BDL & $\mathrm{BDL}$ & $\mathrm{BDL}$ & $\mathrm{BDL}$ & BDL & BDL & BDL & BDL & $\mathrm{BDL}$ & BDL \\
\hline DS 8-5-19 & BDL & BDL & BDL & BDL & BDL & BDL & BDL & BDL & BDL & BDL \\
\hline DS 8-5-19 & $\mathrm{BDL}$ & BDL & BDL & $\mathrm{BDL}$ & $\mathrm{BDL}$ & BDL & BDL & BDL & BDL & BDL \\
\hline DS 8-5-19 & BDL & BDL & BDL & BDL & BDL & BDL & BDL & BDL & BDL & BDL \\
\hline
\end{tabular}




\begin{tabular}{|c|c|c|c|c|c|c|c|c|c|c|}
\hline DS $8-5-19$ & BDL & BDL & BDL & BDL & BDL & BDL & BDL & BDL & BDL & BDL \\
\hline DS 8-5-19 & BDL & BDL & BDL & BDL & BDL & BDL & BDL & BDL & BDL & $\mathrm{BDL}$ \\
\hline DS 8-5-19 & BDL & BDL & BDL & BDL & $\mathrm{BDL}$ & BDL & BDL & BDL & BDL & $\mathrm{BDL}$ \\
\hline US-8-13-19 & BDL & BDL & BDL & BDL & BDL & BDL & BDL & BDL & BDL & $\mathrm{BDL}$ \\
\hline US-8-13-19 & BDL & BDL & BDL & BDL & BDL & BDL & BDL & BDL & BDL & BDL \\
\hline US-8-13-19 & BDL & BDL & BDL & BDL & BDL & BDL & BDL & BDL & BDL & BDL \\
\hline US-8-13-19 & $\mathrm{BDL}$ & BDL & BDL & BDL & BDL & BDL & BDL & BDL & BDL & BDL \\
\hline US-8-13-19 & BDL & BDL & BDL & BDL & BDL & BDL & BDL & BDL & BDL & BDL \\
\hline US-8-13-19 & $\mathrm{BDL}$ & $\mathrm{BDL}$ & BDL & BDL & BDL & BDL & $\mathrm{BDL}$ & $\mathrm{BDL}$ & BDL & BDL \\
\hline US-8-13-19 & BDL & BDL & BDL & BDL & $\mathrm{BDL}$ & BDL & BDL & BDL & BDL & BDL \\
\hline US-8-13-19 & BDL & BDL & BDL & BDL & BDL & BDL & BDL & BDL & BDL & BDL \\
\hline US-8-13-19 & BDL & BDL & BDL & BDL & BDL & BDL & BDL & $\mathrm{BDL}$ & BDL & BDL \\
\hline US-8-13-19 & BDL & BDL & BDL & BDL & BDL & BDL & BDL & BDL & BDL & $\overline{B D L}$ \\
\hline DS 8-13-19 & BDL & BDL & BDL & BDL & $\mathrm{BDL}$ & BDL & BDL & BDL & BDL & BDL \\
\hline DS 8-13-19 & $\mathrm{BDL}$ & $\mathrm{BDL}$ & BDL & BDL & $\mathrm{BDL}$ & BDL & BDL & BDL & BDL & BDL \\
\hline DS 8-13-19 & BDL & BDL & BDL & BDL & BDL & BDL & BDL & BDL & BDL & $\mathrm{BDL}$ \\
\hline DS 8-13-19 & BDL & BDL & BDL & BDL & BDL & BDL & BDL & BDL & BDL & BDL \\
\hline DS 8-13-19 & BDL & BDL & BDL & BDL & BDL & BDL & BDL & BDL & BDL & BDL \\
\hline DS 8-13-19 & BDL & BDL & BDL & BDL & BDL & BDL & BDL & BDL & BDL & BDL \\
\hline DS 8-13-19 & BDL & BDL & BDL & BDL & $\mathrm{BDL}$ & BDL & BDL & BDL & BDL & BDL \\
\hline DS 8-13-19 & $\mathrm{BDL}$ & BDL & $\mathrm{BDL}$ & $\mathrm{BDL}$ & $\mathrm{BDL}$ & $\mathrm{BDL}$ & $\mathrm{BDL}$ & $\mathrm{BDL}$ & $\mathrm{BDL}$ & BDL \\
\hline DS 8-13-19 & BDL & BDL & BDL & BDL & BDL & BDL & BDL & BDL & BDL & BDL \\
\hline DS 8-13-19 & BDL & BDL & BDL & BDL & BDL & BDL & BDL & BDL & BDL & BDL \\
\hline US-10-24-19 & BDL & BDL & BDL & BDL & BDL & BDL & BDL & BDL & BDL & $\mathrm{BDL}$ \\
\hline US-10-24-19 & BDL & BDL & BDL & BDL & BDL & BDL & BDL & BDL & BDL & $\mathrm{BDL}$ \\
\hline US-10-24-19 & $\mathrm{BDL}$ & BDL & BDL & BDL & $\mathrm{BDL}$ & BDL & BDL & BDL & BDL & BDL \\
\hline US-10-24-19 & BDL & BDL & BDL & BDL & BDL & BDL & BDL & BDL & BDL & BDL \\
\hline US-10-24-19 & BDL & BDL & BDL & BDL & BDL & BDL & BDL & BDL & BDL & BDL \\
\hline US-10-24-19 & BDL & BDL & BDL & BDL & BDL & BDL & BDL & BDL & BDL & BDL \\
\hline US-10-24-19 & BDL & BDL & BDL & BDL & BDL & BDL & BDL & BDL & BDL & BDL \\
\hline US-10-24-19 & $\mathrm{BDL}$ & $\mathrm{BDL}$ & $\mathrm{BDL}$ & $\mathrm{BDL}$ & BDL & BDL & BDL & $\mathrm{BDL}$ & $\mathrm{BDL}$ & BDL \\
\hline US-10-24-19 & BDL & $\mathrm{BDL}$ & $\mathrm{BDL}$ & BDL & BDL & $\mathrm{BDL}$ & BDL & $\mathrm{BDL}$ & $\mathrm{BDL}$ & $\mathrm{BDL}$ \\
\hline US-10-24-19 & BDL & $\mathrm{BDL}$ & $\mathrm{BDL}$ & BDL & $\mathrm{BDL}$ & BDL & BDL & BDL & BDL & BDL \\
\hline DS-10-24-19 & BDL & BDL & BDL & BDL & BDL & BDL & $\mathrm{BDL}$ & BDL & BDL & BDL \\
\hline DS-10-24-19 & BDL & BDL & BDL & BDL & $\mathrm{BDL}$ & BDL & BDL & BDL & BDL & BDL \\
\hline DS-10-24-19 & $\mathrm{BDL}$ & BDL & BDL & BDL & BDL & BDL & $\mathrm{BDL}$ & $\mathrm{BDL}$ & $\mathrm{BDL}$ & BDL \\
\hline DS-10-24-19 & BDL & BDL & BDL & BDL & $\mathrm{BDL}$ & BDL & BDL & BDL & BDL & BDL \\
\hline DS-10-24-19 & BDL & BDL & BDL & BDL & BDL & BDL & BDL & BDL & BDL & BDL \\
\hline DS-10-24-19 & BDL & BDL & BDL & BDL & BDL & BDL & BDL & BDL & BDL & BDL \\
\hline DS-10-24-19 & $\mathrm{BDL}$ & BDL & $\mathrm{BDL}$ & $\mathrm{BDL}$ & $\mathrm{BDL}$ & BDL & BDL & $\mathrm{BDL}$ & BDL & BDL \\
\hline DS-10-24-19 & BDL & BDL & BDL & BDL & BDL & BDL & BDL & BDL & BDL & BDL \\
\hline
\end{tabular}




\begin{tabular}{|c|c|c|c|c|c|c|c|c|c|c|}
\hline DS-10-24-19 & BDL & BDL & BDL & BDL & BDL & $\mathrm{BDL}$ & $\mathrm{BDL}$ & BDL & BDL & BDL \\
\hline DS-10-24-19 & BDL & BDL & BDL & BDL & BDL & $\mathrm{BDL}$ & BDL & BDL & $\mathrm{BDL}$ & $\mathrm{BDL}$ \\
\hline US-11-5-19 & BDL & BDL & BDL & BDL & $\mathrm{BDL}$ & $\mathrm{BDL}$ & BDL & BDL & BDL & $\mathrm{BDL}$ \\
\hline US-11-5-19 & BDL & BDL & BDL & BDL & BDL & BDL & BDL & BDL & BDL & $\mathrm{BDL}$ \\
\hline US-11-5-19 & BDL & BDL & BDL & BDL & BDL & BDL & BDL & BDL & BDL & BDL \\
\hline US-11-5-19 & BDL & BDL & BDL & BDL & BDL & BDL & BDL & BDL & BDL & BDL \\
\hline US-11-5-19 & BDL & BDL & BDL & BDL & BDL & BDL & BDL & BDL & $\mathrm{BDL}$ & BDL \\
\hline US-11-5-19 & BDL & BDL & BDL & BDL & BDL & BDL & $\mathrm{BDL}$ & BDL & $\mathrm{BDL}$ & BDL \\
\hline US-11-5-19 & BDL & BDL & BDL & BDL & BDL & $\mathrm{BDL}$ & BDL & BDL & BDL & $\mathrm{BDL}$ \\
\hline US-11-5-19 & BDL & BDL & BDL & BDL & BDL & $\mathrm{BDL}$ & $\mathrm{BDL}$ & BDL & $\mathrm{BDL}$ & BDL \\
\hline US-11-5-19 & BDL & BDL & BDL & BDL & BDL & BDL & BDL & BDL & BDL & BDL \\
\hline US-11-5-19 & BDL & BDL & BDL & BDL & BDL & BDL & BDL & $\mathrm{BDL}$ & $\mathrm{BDL}$ & BDL \\
\hline DS-11-5-19 & BDL & BDL & BDL & BDL & BDL & BDL & BDL & BDL & $\mathrm{BDL}$ & BDL \\
\hline DS-11-5-19 & BDL & BDL & BDL & BDL & BDL & BDL & BDL & BDL & $\mathrm{BDL}$ & BDL \\
\hline DS-11-5-19 & BDL & BDL & BDL & BDL & BDL & BDL & BDL & BDL & $\mathrm{BDL}$ & BDL \\
\hline DS-11-5-19 & BDL & BDL & BDL & BDL & BDL & BDL & BDL & BDL & $\mathrm{BDL}$ & BDL \\
\hline DS-11-5-19 & BDL & BDL & BDL & BDL & BDL & BDL & $\mathrm{BDL}$ & BDL & BDL & BDL \\
\hline DS-11-5-19 & BDL & BDL & BDL & BDL & BDL & BDL & $\mathrm{BDL}$ & BDL & BDL & BDL \\
\hline DS-11-5-19 & BDL & BDL & BDL & BDL & BDL & BDL & BDL & BDL & BDL & BDL \\
\hline DS-11-5-19 & BDL & BDL & BDL & BDL & $\mathrm{BDL}$ & BDL & $\mathrm{BDL}$ & $\mathrm{BDL}$ & $\mathrm{BDL}$ & BDL \\
\hline DS-11-5-19 & $\mathrm{BDL}$ & BDL & $\mathrm{BDL}$ & $\mathrm{BDL}$ & $\mathrm{BDL}$ & $\mathrm{BDL}$ & $\mathrm{BDL}$ & $\mathrm{BDL}$ & $\mathrm{BDL}$ & BDL \\
\hline DS-11-5-19 & BDL & BDL & BDL & BDL & BDL & BDL & $\mathrm{BDL}$ & BDL & BDL & BDL \\
\hline US-11-7-19 & $\mathrm{BDL}$ & $\mathrm{BDL}$ & $\mathrm{BDL}$ & BDL & BDL & BDL & $\mathrm{BDL}$ & $\mathrm{BDL}$ & $\mathrm{BDL}$ & BDL \\
\hline US-11-7-19 & BDL & BDL & BDL & BDL & BDL & $\mathrm{BDL}$ & $\mathrm{BDL}$ & BDL & $\mathrm{BDL}$ & $\mathrm{BDL}$ \\
\hline US-11-7-19 & BDL & BDL & BDL & BDL & BDL & BDL & BDL & BDL & $\mathrm{BDL}$ & $\mathrm{BDL}$ \\
\hline US-11-7-19 & $\mathrm{BDL}$ & $\mathrm{BDL}$ & $\mathrm{BDL}$ & $\mathrm{BDL}$ & $\mathrm{BDL}$ & BDL & BDL & BDL & $\mathrm{BDL}$ & BDL \\
\hline US-11-7-19 & BDL & BDL & BDL & BDL & BDL & BDL & BDL & BDL & $\mathrm{BDL}$ & BDL \\
\hline US-11-7-19 & BDL & BDL & BDL & BDL & BDL & BDL & BDL & BDL & BDL & BDL \\
\hline US-11-7-19 & BDL & BDL & BDL & BDL & BDL & BDL & $\mathrm{BDL}$ & BDL & $\mathrm{BDL}$ & BDL \\
\hline US-11-7-19 & BDL & BDL & BDL & BDL & BDL & BDL & $\mathrm{BDL}$ & BDL & BDL & BDL \\
\hline US-11-7-19 & $\mathrm{BDL}$ & BDL & $\mathrm{BDL}$ & BDL & BDL & BDL & BDL & BDL & BDL & $\mathrm{BDL}$ \\
\hline US-11-7-19 & BDL & BDL & BDL & BDL & BDL & BDL & $\mathrm{BDL}$ & BDL & BDL & BDL \\
\hline DS-11-7-19 & BDL & $\mathrm{BDL}$ & $\mathrm{BDL}$ & BDL & $\mathrm{BDL}$ & $\mathrm{BDL}$ & $\mathrm{BDL}$ & BDL & $\mathrm{BDL}$ & BDL \\
\hline DS-11-7-19 & BDL & BDL & BDL & BDL & BDL & BDL & BDL & BDL & BDL & BDL \\
\hline DS-11-7-19 & BDL & BDL & BDL & BDL & $\mathrm{BDL}$ & BDL & $\mathrm{BDL}$ & BDL & $\mathrm{BDL}$ & BDL \\
\hline DS-11-7-19 & BDL & BDL & BDL & BDL & BDL & BDL & BDL & BDL & $\mathrm{BDL}$ & BDL \\
\hline DS-11-7-19 & BDL & $\mathrm{BDL}$ & BDL & BDL & $\mathrm{BDL}$ & BDL & BDL & BDL & $\mathrm{BDL}$ & BDL \\
\hline DS-11-7-19 & $\mathrm{BDL}$ & BDL & $\mathrm{BDL}$ & $\mathrm{BDL}$ & BDL & $\mathrm{BDL}$ & $\mathrm{BDL}$ & $\mathrm{BDL}$ & BDL & $\mathrm{BDL}$ \\
\hline DS-11-7-19 & BDL & BDL & BDL & BDL & BDL & BDL & BDL & BDL & BDL & BDL \\
\hline DS-11-7-19 & $\mathrm{BDL}$ & BDL & $\mathrm{BDL}$ & $\mathrm{BDL}$ & $\mathrm{BDL}$ & $\mathrm{BDL}$ & $\mathrm{BDL}$ & $\mathrm{BDL}$ & $\mathrm{BDL}$ & BDL \\
\hline DS-11-7-19 & BDL & BDL & BDL & BDL & BDL & BDL & BDL & BDL & BDL & BDL \\
\hline
\end{tabular}




\begin{tabular}{|c|c|c|c|c|c|c|c|c|c|c|}
\hline DS-11-7-19 & BDL & BDL & BDL & BDL & BDL & BDL & BDL & BDL & BDL & BDL \\
\hline US-11-16-19 & BDL & BDL & BDL & BDL & BDL & BDL & BDL & BDL & BDL & $\mathrm{BDL}$ \\
\hline US-11-16-19 & BDL & BDL & BDL & BDL & $\mathrm{BDL}$ & BDL & BDL & BDL & BDL & $\mathrm{BDL}$ \\
\hline US-11-16-19 & BDL & BDL & BDL & BDL & BDL & BDL & BDL & BDL & BDL & $\mathrm{BDL}$ \\
\hline US-11-16-19 & BDL & BDL & BDL & BDL & BDL & BDL & BDL & BDL & BDL & BDL \\
\hline US-11-16-19 & BDL & BDL & BDL & BDL & BDL & BDL & BDL & BDL & BDL & BDL \\
\hline US-11-16-19 & BDL & BDL & BDL & BDL & BDL & BDL & BDL & BDL & BDL & BDL \\
\hline US-11-16-19 & BDL & BDL & BDL & BDL & BDL & BDL & BDL & BDL & BDL & BDL \\
\hline US-11-16-19 & $\mathrm{BDL}$ & $\mathrm{BDL}$ & BDL & BDL & BDL & $\mathrm{BDL}$ & $\mathrm{BDL}$ & BDL & BDL & BDL \\
\hline US-11-16-19 & BDL & BDL & BDL & BDL & $\mathrm{BDL}$ & BDL & BDL & BDL & BDL & BDL \\
\hline US-11-16-19 & BDL & BDL & BDL & BDL & BDL & BDL & BDL & BDL & BDL & BDL \\
\hline DS-11-16-19 & BDL & BDL & BDL & BDL & BDL & BDL & BDL & BDL & BDL & BDL \\
\hline DS-11-16-19 & BDL & BDL & BDL & BDL & BDL & BDL & BDL & BDL & BDL & $\overline{B D L}$ \\
\hline DS-11-16-19 & BDL & BDL & BDL & BDL & $\mathrm{BDL}$ & BDL & BDL & BDL & BDL & BDL \\
\hline DS-11-16-19 & BDL & $\mathrm{BDL}$ & BDL & BDL & BDL & BDL & BDL & BDL & BDL & BDL \\
\hline DS-11-16-19 & BDL & $\mathrm{BDL}$ & BDL & BDL & BDL & BDL & BDL & BDL & BDL & $\mathrm{BDL}$ \\
\hline DS-11-16-19 & BDL & BDL & BDL & BDL & BDL & BDL & BDL & BDL & BDL & BDL \\
\hline DS-11-16-19 & BDL & BDL & BDL & BDL & BDL & BDL & BDL & BDL & BDL & BDL \\
\hline DS-11-16-19 & BDL & BDL & BDL & BDL & BDL & BDL & BDL & BDL & BDL & BDL \\
\hline DS-11-16-19 & BDL & BDL & BDL & BDL & $\mathrm{BDL}$ & BDL & BDL & BDL & BDL & BDL \\
\hline DS-11-16-19 & $\mathrm{BDL}$ & BDL & $\mathrm{BDL}$ & $\mathrm{BDL}$ & $\mathrm{BDL}$ & $\mathrm{BDL}$ & $\mathrm{BDL}$ & $\mathrm{BDL}$ & $\mathrm{BDL}$ & BDL \\
\hline US-11-19-19 & BDL & BDL & BDL & BDL & BDL & BDL & BDL & BDL & BDL & BDL \\
\hline US-11-19-19 & BDL & BDL & BDL & BDL & BDL & BDL & BDL & BDL & BDL & BDL \\
\hline US-11-19-19 & $\mathrm{BDL}$ & BDL & BDL & BDL & $\mathrm{BDL}$ & BDL & BDL & BDL & BDL & $\mathrm{BDL}$ \\
\hline US-11-19-19 & BDL & BDL & BDL & BDL & BDL & BDL & BDL & BDL & BDL & $\mathrm{BDL}$ \\
\hline US-11-19-19 & $\mathrm{BDL}$ & $\mathrm{BDL}$ & $\mathrm{BDL}$ & $\mathrm{BDL}$ & $\mathrm{BDL}$ & BDL & BDL & BDL & BDL & BDL \\
\hline US-11-19-19 & BDL & BDL & BDL & BDL & BDL & BDL & BDL & BDL & BDL & BDL \\
\hline US-11-19-19 & BDL & BDL & BDL & BDL & BDL & BDL & BDL & BDL & BDL & BDL \\
\hline US-11-19-19 & BDL & BDL & BDL & BDL & BDL & BDL & BDL & BDL & BDL & BDL \\
\hline US-11-19-19 & BDL & BDL & BDL & BDL & BDL & BDL & BDL & BDL & BDL & BDL \\
\hline US-11-19-19 & $\mathrm{BDL}$ & $\mathrm{BDL}$ & $\mathrm{BDL}$ & $\mathrm{BDL}$ & BDL & BDL & $\mathrm{BDL}$ & $\mathrm{BDL}$ & $\mathrm{BDL}$ & BDL \\
\hline DS-11-19-19 & BDL & $\mathrm{BDL}$ & $\mathrm{BDL}$ & BDL & BDL & $\mathrm{BDL}$ & BDL & $\mathrm{BDL}$ & $\mathrm{BDL}$ & $\mathrm{BDL}$ \\
\hline DS-11-19-19 & BDL & BDL & BDL & BDL & $\mathrm{BDL}$ & BDL & BDL & BDL & BDL & BDL \\
\hline DS-11-19-19 & BDL & BDL & BDL & $\mathrm{BDL}$ & BDL & $\mathrm{BDL}$ & $\mathrm{BDL}$ & BDL & BDL & BDL \\
\hline DS-11-19-19 & BDL & BDL & BDL & BDL & $\mathrm{BDL}$ & BDL & BDL & BDL & BDL & BDL \\
\hline DS-11-19-19 & BDL & BDL & $\mathrm{BDL}$ & BDL & BDL & BDL & BDL & BDL & BDL & BDL \\
\hline DS-11-19-19 & BDL & $\mathrm{BDL}$ & BDL & BDL & $\mathrm{BDL}$ & BDL & BDL & BDL & BDL & BDL \\
\hline DS-11-19-19 & BDL & BDL & BDL & BDL & BDL & BDL & BDL & BDL & BDL & BDL \\
\hline DS-11-19-19 & BDL & BDL & BDL & BDL & BDL & BDL & BDL & BDL & BDL & BDL \\
\hline DS-11-19-19 & BDL & BDL & BDL & $\mathrm{BDL}$ & $\mathrm{BDL}$ & BDL & BDL & BDL & BDL & BDL \\
\hline DS-11-19-19 & BDL & BDL & BDL & BDL & BDL & BDL & BDL & BDL & BDL & BDL \\
\hline
\end{tabular}




\section{APPENDIX B: CHLORIDE CONCENTRATIONS}

\begin{tabular}{|c|c|}
\hline Sample & Chloride \\
\hline $\begin{array}{c}\text { US }=\text { Upstream } \\
\text { DS }=\text { Downstream }\end{array}$ & $\mathrm{mg} / \mathrm{L}$ \\
\hline US-7-6-19 & 124.11 \\
\hline US-7-6-19 & 125.55 \\
\hline US-7-6-19 & 126.31 \\
\hline US-7-6-19 & 126.93 \\
\hline US-7-6-19 & 127.38 \\
\hline US-7-6-19 & 127.77 \\
\hline US-7-6-19 & 128.07 \\
\hline US-7-6-19 & 128.61 \\
\hline US-7-6-19 & 128.71 \\
\hline US-7-6-19 & 129.01 \\
\hline DS-7-6-19 & 130.20 \\
\hline DS-7-6-19 & 130.45 \\
\hline DS-7-6-19 & 130.37 \\
\hline DS-7-6-19 & 131.00 \\
\hline DS-7-6-19 & 131.04 \\
\hline DS-7-6-19 & 132.79 \\
\hline DS-7-6-19 & 131.62 \\
\hline DS-7-6-19 & 131.61 \\
\hline DS-7-6-19 & 131.71 \\
\hline DS-7-6-19 & 131.95 \\
\hline US-7-8-19 & 130.44 \\
\hline US-7-8-19 & 133.23 \\
\hline US-7-8-19 & 138.36 \\
\hline US-7-8-19 & 137.83 \\
\hline US-7-8-19 & 127.29 \\
\hline US-7-8-19 & 137.92 \\
\hline US-7-8-19 & 110.14 \\
\hline US-7-8-19 & 135.78 \\
\hline US-7-8-19 & 135.50 \\
\hline US-7-8-19 & 138.28 \\
\hline DS-7-8-19 & 139.18 \\
\hline DS-7-8-19 & 135.11 \\
\hline DS-7-8-19 & 138.28 \\
\hline DS-7-8-19 & 138.80 \\
\hline DS-7-8-19 & 132.61 \\
\hline DS-7-8-19 & 148.90 \\
\hline DS-7-8-19 & 113.55 \\
\hline
\end{tabular}




\begin{tabular}{|c|c|}
\hline DS-7-8-19 & 138.85 \\
\hline DS-7-8-19 & 138.67 \\
\hline DS-7-8-19 & 64.57 \\
\hline US-7-30-19 & 117.92 \\
\hline US-7-30-19 & 107.56 \\
\hline US-7-30-19 & 108.87 \\
\hline US-7-30-19 & 117.57 \\
\hline US-7-30-19 & 117.31 \\
\hline US-7-30-19 & 117.57 \\
\hline US-7-30-19 & 116.76 \\
\hline US-7-30-19 & 117.68 \\
\hline US-7-30-19 & 116.84 \\
\hline US-7-30-19 & 116.93 \\
\hline DS-7-30-19 & 115.66 \\
\hline DS-7-30-19 & 115.07 \\
\hline DS-7-30-19 & 116.83 \\
\hline DS-7-30-19 & 116.47 \\
\hline DS-7-30-19 & 117.03 \\
\hline DS-7-30-19 & 116.93 \\
\hline DS-7-30-19 & 117.33 \\
\hline DS-7-30-19 & 117.67 \\
\hline DS-7-30-19 & 116.63 \\
\hline DS-7-30-19 & 117.28 \\
\hline US-8-5-19 & 87.39 \\
\hline US-8-5-19 & 102.56 \\
\hline US-8-5-19 & 103.60 \\
\hline US-8-5-19 & 105.28 \\
\hline US-8-5-19 & 104.46 \\
\hline US-8-5-19 & 104.77 \\
\hline US-8-5-19 & 105.19 \\
\hline US-8-5-19 & 104.01 \\
\hline US-8-5-19 & 103.96 \\
\hline US-8-5-19 & 104.81 \\
\hline DS 8-5-19 & 105.56 \\
\hline DS 8-5-19 & 104.18 \\
\hline DS 8-5-19 & 104.51 \\
\hline DS 8-5-19 & 105.66 \\
\hline DS 8-5-19 & 105.94 \\
\hline DS 8-5-19 & 106.14 \\
\hline DS 8-5-19 & 105.43 \\
\hline DS 8-5-19 & 107.30 \\
\hline
\end{tabular}




\begin{tabular}{|c|c|}
\hline DS 8-5-19 & 105.94 \\
\hline DS 8-5-19 & 106.86 \\
\hline US-8-13-19 & 133.36 \\
\hline US-8-13-19 & 132.50 \\
\hline US-8-13-19 & 132.78 \\
\hline US-8-13-19 & 121.82 \\
\hline US-8-13-19 & 131.54 \\
\hline US-8-13-19 & 130.94 \\
\hline US-8-13-19 & 120.32 \\
\hline US-8-13-19 & 133.77 \\
\hline US-8-13-19 & 121.70 \\
\hline US-8-13-19 & 134.31 \\
\hline DS 8-13-19 & 117.60 \\
\hline DS 8-13-19 & 118.21 \\
\hline DS 8-13-19 & 119.80 \\
\hline DS 8-13-19 & 116.36 \\
\hline DS 8-13-19 & 120.86 \\
\hline DS 8-13-19 & 119.13 \\
\hline DS 8-13-19 & 118.68 \\
\hline DS 8-13-19 & 114.99 \\
\hline DS 8-13-19 & 131.90 \\
\hline DS 8-13-19 & 124.00 \\
\hline US-10-24-19 & 166.23 \\
\hline US-10-24-19 & 148.65 \\
\hline US-10-24-19 & 152.55 \\
\hline US-10-24-19 & 121.25 \\
\hline US-10-24-19 & 74.58 \\
\hline US-10-24-19 & 87.48 \\
\hline US-10-24-19 & 108.45 \\
\hline US-10-24-19 & 160.39 \\
\hline US-10-24-19 & 79.66 \\
\hline US-10-24-19 & 100.05 \\
\hline DS-10-24-19 & 146.14 \\
\hline DS-10-24-19 & 64.80 \\
\hline DS-10-24-19 & 79.23 \\
\hline DS-10-24-19 & 165.32 \\
\hline DS-10-24-19 & 80.77 \\
\hline DS-10-24-19 & 64.86 \\
\hline DS-10-24-19 & 163.31 \\
\hline DS-10-24-19 & 95.16 \\
\hline DS-10-24-19 & 72.27 \\
\hline
\end{tabular}




\begin{tabular}{|c|c|}
\hline DS-10-24-19 & 144.75 \\
\hline US-11-5-19 & 165.45 \\
\hline US-11-5-19 & 166.50 \\
\hline US-11-5-19 & 166.89 \\
\hline US-11-5-19 & 167.26 \\
\hline US-11-5-19 & 167.71 \\
\hline US-11-5-19 & 166.18 \\
\hline US-11-5-19 & 168.21 \\
\hline US-11-5-19 & 168.53 \\
\hline US-11-5-19 & 168.96 \\
\hline US-11-5-19 & 169.29 \\
\hline DS-11-5-19 & 167.09 \\
\hline DS-11-5-19 & 170.45 \\
\hline DS-11-5-19 & 171.11 \\
\hline DS-11-5-19 & 171.35 \\
\hline DS-11-5-19 & 171.85 \\
\hline DS-11-5-19 & 172.24 \\
\hline DS-11-5-19 & 172.46 \\
\hline DS-11-5-19 & 172.86 \\
\hline DS-11-5-19 & 173.45 \\
\hline DS-11-5-19 & 173.28 \\
\hline US-11-7-19 & 82.87 \\
\hline US-11-7-19 & 133.36 \\
\hline US-11-7-19 & 134.58 \\
\hline US-11-7-19 & 129.58 \\
\hline US-11-7-19 & 118.09 \\
\hline US-11-7-19 & 134.07 \\
\hline US-11-7-19 & 109.18 \\
\hline US-11-7-19 & 132.60 \\
\hline US-11-7-19 & 97.03 \\
\hline US-11-7-19 & 137.58 \\
\hline DS-11-7-19 & 109.33 \\
\hline DS-11-7-19 & 137.12 \\
\hline DS-11-7-19 & 133.93 \\
\hline DS-11-7-19 & 134.34 \\
\hline DS-11-7-19 & 134.21 \\
\hline DS-11-7-19 & 134.82 \\
\hline DS-11-7-19 & 131.81 \\
\hline DS-11-7-19 & 131.67 \\
\hline DS-11-7-19 & 134.17 \\
\hline DS-11-7-19 & 134.20 \\
\hline
\end{tabular}




\begin{tabular}{|c|c|}
\hline US-11-16-19 & 183.07 \\
\hline US-11-16-19 & 144.28 \\
\hline US-11-16-19 & 165.49 \\
\hline US-11-16-19 & 177.33 \\
\hline US-11-16-19 & 198.78 \\
\hline US-11-16-19 & 206.38 \\
\hline US-11-16-19 & 207.70 \\
\hline US-11-16-19 & 156.34 \\
\hline US-11-16-19 & 155.06 \\
\hline US-11-16-19 & 195.46 \\
\hline DS-11-16-19 & 195.38 \\
\hline DS-11-16-19 & 195.03 \\
\hline DS-11-16-19 & 199.77 \\
\hline DS-11-16-19 & 206.01 \\
\hline DS-11-16-19 & 194.41 \\
\hline DS-11-16-19 & 198.12 \\
\hline DS-11-16-19 & 192.74 \\
\hline DS-11-16-19 & 191.35 \\
\hline DS-11-16-19 & 194.49 \\
\hline DS-11-16-19 & 200.75 \\
\hline US-11-19-19 & 182.43 \\
\hline US-11-19-19 & 182.27 \\
\hline US-11-19-19 & 182.42 \\
\hline US-11-19-19 & 182.35 \\
\hline US-11-19-19 & 182.58 \\
\hline US-11-19-19 & 182.14 \\
\hline US-11-19-19 & 182.47 \\
\hline DS-11-19-19 & 183.97 \\
\hline US-11-19-19 & 183.50 \\
\hline US-11-19-19 & 146.18 \\
\hline DS-11-19-19 & 181.76 \\
\hline DS-11-19-19-19-19 & 181.77 \\
\hline DS-11-19-19 & 173.05 \\
\hline DS-11-19-19 & 181.69 \\
\hline DS-11-19-19 & 181.51 \\
\hline DS-19-19 & 143.49 \\
\hline & \\
\hline & 183 \\
\hline DS-19 \\
\hline
\end{tabular}


APPENDIX C: FIELD PARAMETERS

\begin{tabular}{|c|r|r|c|}
\hline $\begin{array}{c}\text { Sample } \\
\text { US = Upstream } \\
\text { Downstream }\end{array}$ & Temp & DO & pH \\
\hline US-7-6-19 & 23.40 & mg/L & \\
\hline DS-7-6-19 & 23.40 & 4.90 & 7.51 \\
\hline US-7-8-19 & 21.40 & 5.55 & 7.64 \\
\hline DS-7-8-19 & 21.50 & 5.57 & 7.75 \\
\hline US-7-30-19 & 22.90 & 5.90 & 7.22 \\
\hline DS-7-30-19 & 23.10 & 5.17 & 7.22 \\
\hline US-8-5-19 & 23.70 & 5.34 & 7.55 \\
\hline DS 8-5-19 & 23.60 & 4.92 & 7.21 \\
\hline US-8-13-19 & 23.80 & 5.22 & 7.65 \\
\hline DS 8-13-19 & 23.80 & 5.28 & 7.23 \\
\hline US-10-24-19 & 15.10 & 5.45 & 7.48 \\
\hline DS-10-24-19 & 15.00 & 5.16 & 7.45 \\
\hline US-11-5-19 & 11.30 & 6.87 & 7.34 \\
\hline DS-11-5-19 & 11.30 & 6.88 & 7.31 \\
\hline US-11-7-19 & 10.90 & 7.28 & 7.28 \\
\hline DS-11-7-19 & 10.90 & 8.40 & 7.46 \\
\hline US-11-16-19 & 9.40 & 6.45 & 7.42 \\
\hline DS-11-16-19 & 9.30 & 7.02 & 7.25 \\
\hline US-11-19-19 & 11.00 & 5.16 & 7.53 \\
\hline DS-11-19-19 & 10.90 & 5.03 & 7.17 \\
\hline
\end{tabular}

